Article

\title{
Legality Constraints: The Emergence of a Dual Market for Tropical Timber Products?
}

\author{
Mauro Masiero ${ }^{1, \dagger}$, Davide Pettenella ${ }^{1, \dagger, *}$ and Paolo Omar Cerutti ${ }^{2, \dagger}$
}

1 TeSAF Department, University of Padova, Viale dell'Università 16, Legnaro (PD) 35020, Italy; E-Mail: mauro.masiero@unipd.it

2 CIFOR, Centre for International Forestry Research, Nairobi 00100, Kenya;

E-Mail: p.cerutti@cgiar.org

$\dagger$ These authors contributed equally to this work.

* Author to whom correspondence should be addressed; E-Mail: davide.pettenella@unipd.it; Tel.: +39-49-827-2741; Fax: +39-49-827-2750.

Academic Editors: Thomas J. Straka and Eric J. Jokela

Received: 3 July 2015 / Accepted: 21 September 2015 / Published: 30 September 2015

\begin{abstract}
The European Union (EU), the United States of America (USA), and Australia have adopted specific measures to avoid the placing of illegal timber on their markets. These measures might encourage the diversion of timber products from traditional large importers to destinations with a less stringent regulatory framework. During 2001-2013, the international trade in tropical primary timber products (logs; sawnwood; veneers and plywood) decreased by $13 \%$ in volume and increased by almost $5 \%$ in value. Imports by Australia, the EU, and the USA halved, while those by emerging economies such as China and India initially remained stable and later increased. Tropical timber products-mostly logs and sawnwood - might have been diverted towards emerging economies over the period considered. This general trend is confirmed when analyzing imports from countries that are implementing voluntary partnership agreements (VPA) within the EU Forest Law Enforcement, Governance and Trade (FLEGT) Action Plan. Several factors might influence these market dynamics, including changes induced by the 2008 financial crisis and the increasing domestic demand for timber products by emerging nations. The effects of legality measures on market trends are still unclear. Nonetheless, they might have encouraged uncertainty with regards to traditional importers and favored emerging ones.
\end{abstract}


Keywords: illegal logging; timber trade; tropical timber; market diversion; legality standards; emerging economies; EUTR; Lacey Act; Australian Illegal Logging Prohibition Act; FLEGT

\section{Introduction}

Illegal logging (IL) and the associated trade in illegally sourced products have been prominent global forest policy issues since the 1992 United Nations Conference on Environment and Development in Rio de Janeiro [1]. Many studies on IL, law enforcement, and the timber trade have assessed their local, regional, and global socioeconomic and environmental impact over the years [2-8]. In particular, threats to wildlife [9] and carbon emissions [10] have been highlighted, together with revenue losses [11] and timber price depression [3], in addition to links with corruption practices [12-14] and social conflicts [15]. In 2012, the United Nations Environment Program (UNEP) and the International Criminal Police Organization (ICPO)-INTERPOL estimated that total losses from IL ranged between USD 30 and 100 billion annually, i.e., 10\% to 30\% of the total global wood trade [16]. According to the same source and other studies (e.g., [17]) the three major importers of illegal timber were the United States of America (USA), the European Union (EU), and China.

The international timber legality assurance regime includes a variety of interrelated public and private policy instruments $[18,19]$. In particular, rising public concern about IL and the timber trade is inducing many countries/regions, such as the EU, the USA, and Australia, to introduce legality standards that affect the timber traded on their markets. The adoption and implementation of the EU Timber Regulation (EUTR; [20]) within the framework of the EU Forest Law Enforcement Governance and Trade (FLEGT) Action Plan, the amendment of the Lacey Act [21], and the enactment of the Australian Illegal Logging Prohibition Act [22] are imposing stricter requirements on timber exported to most Northern countries/regions. Apart from Australia, the EU, and the USA, few countries have timber-specific trade laws focused on legality issues. Some governments have adopted procurement regulations specifically for timber; they often indicate that timber must be verified as originating from sustainably managed forests. In some cases, regulations go further, for example in Japanese legislation, which specifically addresses the illegal timber trade through the Goho-Wood initiative (for further information see: www.goho-wood.jp/world/). Due to their voluntary nature, however, Japanese rules are viewed as weaker than those implemented in Australia, the EU, and the USA [23].

The impacts of timber-trade legality regulations have been addressed by some preliminary studies, but attention has been focused on single regulations (e.g., [24-27]) and/or countries/regions (e.g., [28-31]). Timber-trade legality regulations can reduce the amount of illegally sourced timber being placed on the market. Yet their requirements do not cover all timber traded on a global level and they might have side effects, including the diversion of timber exports to destinations with less stringent regulatory frameworks. Indeed, part of the timber that is imported and locally consumed by emerging economies (such as India and China) is subject to less strict or no requirements and limitations [24]. Such countries may thus become the repository of illegally harvested timber previously exported elsewhere, 
with consequences for trade flows and, ultimately, for the conservation and responsible management of forest resources. The final potential consequence of these market- and policy-driven dynamics within the international forest regime might be the creation of a dual market, with trade flows determined by the strictness of the constraints applied in consumer countries.

Building on the abovementioned considerations and assumptions, the present study aims to analyze and discuss:

- the state of the timber flows at global level over the 2001-2013 period, with a focus on tropical timber and timber-based products;

- the changes in timber flows to the EU, the USA, and Australian markets from 2001 to 2013, a period that includes the years of discussions, preparation, adoption, and eventual implementation of their respective legality verification systems (i.e., the EUTR of 2103, the Lacey Act amendment of 2008, and the Australian Illegal Logging Prohibition Act of 2012), and the corresponding changes in timber flows and market structure in selected emerging economies without specific legality verification regulations;

- the magnitude of the possible ensuing dual market and the potential driving forces behind it.

\section{Methodology}

Three main methodological steps were undertaken to conduct this study: product and country selection, with special emphasis on selecting the most appropriate database in relation to the study scope, data cleaning, and elaboration, followed by data processing. Appendix A presents the detailed procedure used to clean and elaborate data, while product and country selection criteria are described below.

\subsection{Product Selection}

Secondary data on traded volumes and values have been gathered from the United Nations Commodity Trade Statistics Database (UN COMTRADE), where commodity groups are recorded according to the Harmonized Commodity Description and Coding System (Harmonized System, or HS), or extended versions based on HS, such as the Combined Nomenclature (CN) used by EU Member Countries. Based on a literature review (e.g., [32]) and discussion with experts, it was decided to focus the analysis on four commodity groups (i.e., logs, sawnwood, plywood, and veneers) (Table 1).

These four commodity groups were selected primarily because: (i) they represent the products to which the FLEGT licensing scheme applies, irrespective of the partner country [33]; (ii) contrary to other international datasets (e.g., FAOSTAT) they include sub-categories (i.e., sub-codes) with specific reference to tropical timber products; and (iii) they are labeled as primary products by the International Tropical Timber Organization (ITTO) in its Annual Review and Assessment of the World Timber situation. Altogether, the four groups cover 17 of the six-digit $\mathrm{CN}$ codes (i.e., headings and sub-headings) included within the EUTR scope. These do not comprise many finished or semi-finished products (e.g., chairs or printed items such as books) that are not included within the scope of timber trade legality regulations, and in particular within the EUTR scope, as recent critiques have highlighted [34,35]. With our choice of groups, we do not intend to ignore the relevance of these 
criticisms. Rather, our selection was made to keep the study more focused and to avoid generating an excessive amount of data to be analyzed, hence making elaboration unfeasible.

Data cover the 2001-2013 period as the longest time series available on the UN COMTRADE database for the commodities under evaluation.

Table 1. Commodity groups analyzed in the research, according to the UN COMTRADE classification.

\begin{tabular}{|c|c|c|}
\hline $\begin{array}{l}\text { Commodity Groups and } \\
\text { Sub-Groups }\end{array}$ & Short Description & $\begin{array}{c}\text { CN } \\
\text { Code }\end{array}$ \\
\hline Logs or roundwood & Wood in the rough or roughly squared & 4403 \\
\hline Meranti Red Dark & Dark Red Meranti, Light Red Meranti, and Meranti Bakau & 440341 \\
\hline $\begin{array}{l}\text { Other tropical wood not elsewhere } \\
\text { specified (n.e.s.) }\end{array}$ & Tropical wood logs (not elsewhere specified) & 440349 \\
\hline Sawnwood & Wood sawn, chipped lengthwise, sliced or peeled & 4407 \\
\hline Mahogany (Swietenia spp.) & $\begin{array}{l}\text { Mahogany (Swietenia spp.), sawn or chipped lengthwise, } \\
\text { sliced or peeled }\end{array}$ & 440721 \\
\hline Virola, Imbuia and Balsa & $\begin{array}{l}\text { Virola/Imbuia and Balsa wood sawn or chipped lengthwise, } \\
\text { sliced or peeled }\end{array}$ & 440722 \\
\hline Baboen, Mahogany, Imbuia, Balsa & $\begin{array}{l}\text { Baboen, Mahogany (Swietenia spp.), Imbuia, Balsa wood } \\
\text { sawn or chipped lengthwise, sliced or peeled }\end{array}$ & 440723 \\
\hline Virola, Mahogany & $\begin{array}{l}\text { Virola, Mahogany (Swietenia spp.), sawn or chipped } \\
\text { lengthwise, sliced or peeled }\end{array}$ & 440724 \\
\hline Meranti Red Dark & $\begin{array}{l}\text { Dark Red Meranti, Light Red Meranti, and Meranti Bakau, } \\
\text { sawn or chipped lengthwise, sliced or peeled }\end{array}$ & 440725 \\
\hline $\begin{array}{l}\text { White Lauan, White Meranti, White } \\
\text { Seraya, Yellow Meranti and Alan }\end{array}$ & $\begin{array}{l}\text { White Lauan, White Meranti, White Seraya, Yellow Meranti, } \\
\text { and Alan, sawn or chipped lengthwise, sliced or peeled }\end{array}$ & 440726 \\
\hline $\begin{array}{l}\text { Virola, Mahogany (Swietenia spp.), } \\
\text { Imbuia and Balsa }\end{array}$ & $\begin{array}{l}\text { Virola, Mahogany (Swietenia spp.), Imbuia, and Balsa, } \\
\text { non-coniferous species, sawn or chipped lengthwise, sliced }\end{array}$ & 440727 \\
\hline Iroko & $\begin{array}{l}\text { Iroko wood sawn or chipped lengthwise, sliced or peeled, } \\
\text { over } 6 \mathrm{~mm} \text { thick }\end{array}$ & 440728 \\
\hline Other tropical wood n.e.s. & Tropical sawnwood (not elsewhere specified) & 440729 \\
\hline Veneers & Veneers and sheets for plywood, etc. $<6 \mathrm{~mm}$ thick & 4408 \\
\hline Meranti Red Dark & $\begin{array}{l}\text { Dark Red Meranti, Light Red Meranti, and Meranti Bakau, } \\
\text { veneer or plywood sheets }\end{array}$ & 440831 \\
\hline Other tropical wood n.e.s. & Tropical wood veneers (not elsewhere specified) & 440839 \\
\hline Plywood & Plywood, veneered panels, and similar laminated wood & 4412 \\
\hline Plywood, all wood & $\begin{array}{l}\text { Plywood all wood, each } \leq 6 \mathrm{~mm} \text {, with at least one outer ply of } \\
\text { tropical wood }\end{array}$ & 441213 \\
\hline Plywood, outer ply of tropical wood & $\begin{array}{l}\text { Plywood not all wood and/or at least one ply }>6 \mathrm{~mm} \text {, with at } \\
\text { least one outer ply of tropical wood }\end{array}$ & 441222 \\
\hline Plywood n.e.s., 1-ply tropic & $\begin{array}{l}\text { Plywood not all wood and/or at least one ply }>6 \mathrm{~mm} \text {, with at } \\
\text { least one outer ply of non-coniferous tropical wood }\end{array}$ & 441229 \\
\hline $\begin{array}{l}\text { Plywood, outer ply of other } \\
\text { tropical wood }\end{array}$ & $\begin{array}{l}\text { Plywood not all wood and/or at least one ply }>6 \mathrm{~mm} \text {, with at } \\
\text { least one outer ply of other tropical wood }\end{array}$ & 441231 \\
\hline
\end{tabular}




\subsection{Country Selection}

Trade data have been analyzed both at the global scale and with reference to six selected countries/regions, i.e., Australia, China, the European Union (EU-28), India, the USA, and Vietnam. Australia, the EU-28, and USA have been selected because of their role as traditional, large importers and their recently implemented policies and regulations aiming to tackle the illegal timber trade on their markets. China, India, and Vietnam have been chosen because in recent years they have become among the world's largest importers for many primary timber products and have an expanding timber processing industry. For example, some $50 \%$ to $80 \%$ of Vietnam's timber supply was imported [36], while Indian timber imports as a percentage of national consumption increased from just 2\% in 1994 to $17 \%$ in 2006 and more than $30 \%$ in recent years [37].

Imports by China, India, and Vietnam aim to meet both the growing domestic consumption and the demand from local companies, which later re-export value-added products to other countries. Indeed, trade flows among selected countries are also relevant: a large amount of re-exported products goes to the European, Chinese, and American markets. For example, it has been estimated that in 2012, 13\% of Indian exports of products included within the EUTR scope went to the EU, and the United Kingdom (UK) was the largest export market for Indian pulp and paper in recent years [38]. The main export markets for Vietnamese furniture are the USA, Japan, and the EU, while China is the largest market for Vietnamese woodchip, and the USA is one of the main destinations for Vietnamese paper [39].

Due to their role as large importers, geographical position, and historical trade relationships with producing countries that are suspected of IL practices, the selected countries show high rates (9\%-26\%) of illegally sourced imports (Table 2). These figures exclude export-unrelated IL, such as illegal timber used for domestic consumption.

Table 2. Estimated illegal timber import rates by selected countries.

\begin{tabular}{ccc}
\hline \multirow{2}{*}{ Country } & $\begin{array}{c}\text { Illegal Timber Import Rates (\%) } \\
\text { (i.e., \% of Illegally Imported Timber over Total Imports) }\end{array}$ & Sources \\
\hline Australia & 9 & {$[40]$} \\
China & $20-26$ & {$[41]$} \\
EU-28 & $16-19$ & {$[5]$} \\
India & 17 & {$[38]$} \\
USA & $10 *$ & {$[42]$} \\
Vietnam & 20 & {$[41]$} \\
\hline
\end{tabular}

* Paper products not included. EU-28: the European Union

\section{Results}

About 195,000 records were gathered from the UN COMTRADE database with regard to the $17 \mathrm{CN}$ codes corresponding to the four selected product groups. The following sections present detailed findings, per product group, for trade data and imports at global level and by the six selected importers, with a special focus on imports from VPA countries. 


\subsection{Tropical Timber Trade Trends}

Between 2001 and 2013, international trade in primary tropical timber products (logs, sawnwood, veneer, and plywood) decreased by $13 \%$ in volume and increased by almost $5 \%$ in value (Table 3 and Figure 1).

Table 3. International tropical timber trade — in volume and value — for selected product groups, 2001 and 2013.

\begin{tabular}{|c|c|c|c|c|c|c|c|c|c|c|}
\hline \multirow[b]{2}{*}{ CN Code } & \multicolumn{4}{|c|}{2001} & \multicolumn{4}{|c|}{2013} & \multicolumn{2}{|c|}{$2001-2013 \%$ Variation } \\
\hline & $\begin{array}{l}\text { Volume } \\
(\text { CUM *) }\end{array}$ & $\%$ on $\mathrm{T}$ & $\begin{array}{c}\text { Value } \\
\text { (1000 USD) }\end{array}$ & $\%$ on $\mathrm{T}$ & $\begin{array}{l}\text { Volume } \\
\text { (CUM) }\end{array}$ & $\%$ on $\mathrm{T}$ & $\begin{array}{c}\text { Value } \\
\text { (1000 USD) }\end{array}$ & $\%$ on $\mathrm{T}$ & Volume & Value \\
\hline 4403 & $7,106,094$ & 29.6 & $1,436,237$ & 16.8 & $5,794,423$ & 27.8 & $2,115,648$ & 23.6 & -18.5 & 47.3 \\
\hline 4407 & $9,656,470$ & 40.2 & $4,277,011$ & 49.9 & $8,685,690$ & 41.7 & $3,346,510$ & 37.3 & -10.1 & -21.8 \\
\hline 4408 & 701,386 & 2.9 & 420,014 & 4.9 & 415,078 & 2.0 & 464,118 & 5.2 & -40.8 & 10.5 \\
\hline 4412 & $6,531,104$ & 27.2 & $2,434,184$ & 28.4 & $5,945,741$ & 28.5 & $3,044,304$ & 33.9 & -9.0 & 25.1 \\
\hline Total $(\mathrm{T})$ & $23,995,054$ & 100.0 & $8,567,446$ & 100.0 & $20,840,932$ & 100.0 & $8,970,580$ & 100.0 & -13.1 & 4.7 \\
\hline
\end{tabular}

* Cubic meters. Source: own elaboration from [43].

\subsubsection{Logs}

Tropical logs trade at global level showed a decreasing trend between 2001 and $2013(-18.5 \%)$, with some spot recovery (e.g., in 2003, +14\% compared to 2002; or 2011, $+25 \%$ compared to 2010 ). In terms of value, the trend has been the opposite, with a positive relative variation between 2001 and 2013 (+47\%): total value increased up to USD 2.3 billion in 2007 ( $+38 \%$ compared to 2001), then dropped to USD 1.5 billion in 2009 and rose again in the following years $(+39 \%$ in 2013 compared to 2009).

In 2013 the traded volume for selected commodity groups was about cubic meters (CUM) 5.8 million, corresponding to a global value of about USD 2.1 billion. In 2013, China and India were the top global importers of tropical logs (about 66\% of global imports), almost doubling their share from the early 2000s (between 35\% and 43\% altogether). Indeed, among the main importers, only China and India have increased their imports in recent years, with India becoming the third global consumer of tropical logs after Indonesia and Brazil. Growing domestic demand in China and India contributed much to increased imports, as domestic forest removals could not cope with increased consumption.

Conversely, there are several reasons that might explain the decreasing trend in global roundwood trade. First, many tropical countries increased their legally mandated ratio of domestic processing of logs over the past decade: by 2012, processing rates stood at about $99 \%$ in Latin America, at about $92 \%$ in the Asia-Pacific region, and at between 80 and 90\% in Africa [44]. Second, domestic demand increased over the same period in many producing countries, including top producers such as Brazil and Indonesia - which have become major consumers, too-but also China, thus further reducing log availability. Third, many international companies shifted their processing capacity from Northern countries to tropical ones where they owned logging concessions, largely in order to profit from lower costs of labor. Also, in many cases, log quality has been reportedly declining, as a result of a progressive reduction of old growth, higher grade primary forests, and production shifting to 
logged-over and degraded forests [44]. Furthermore, logs exported from West-Central Africa to Asian markets are often low-grade logs that could hardly be exported to different markets. Notwithstanding a decreasing overall quality in roundwood, prices tend to be higher than in the past. This is mostly due to a decreasing availability of tropical logs on the international market, due to the implementation of long-promised log export bans in some key countries (e.g., Gabon in 2010).
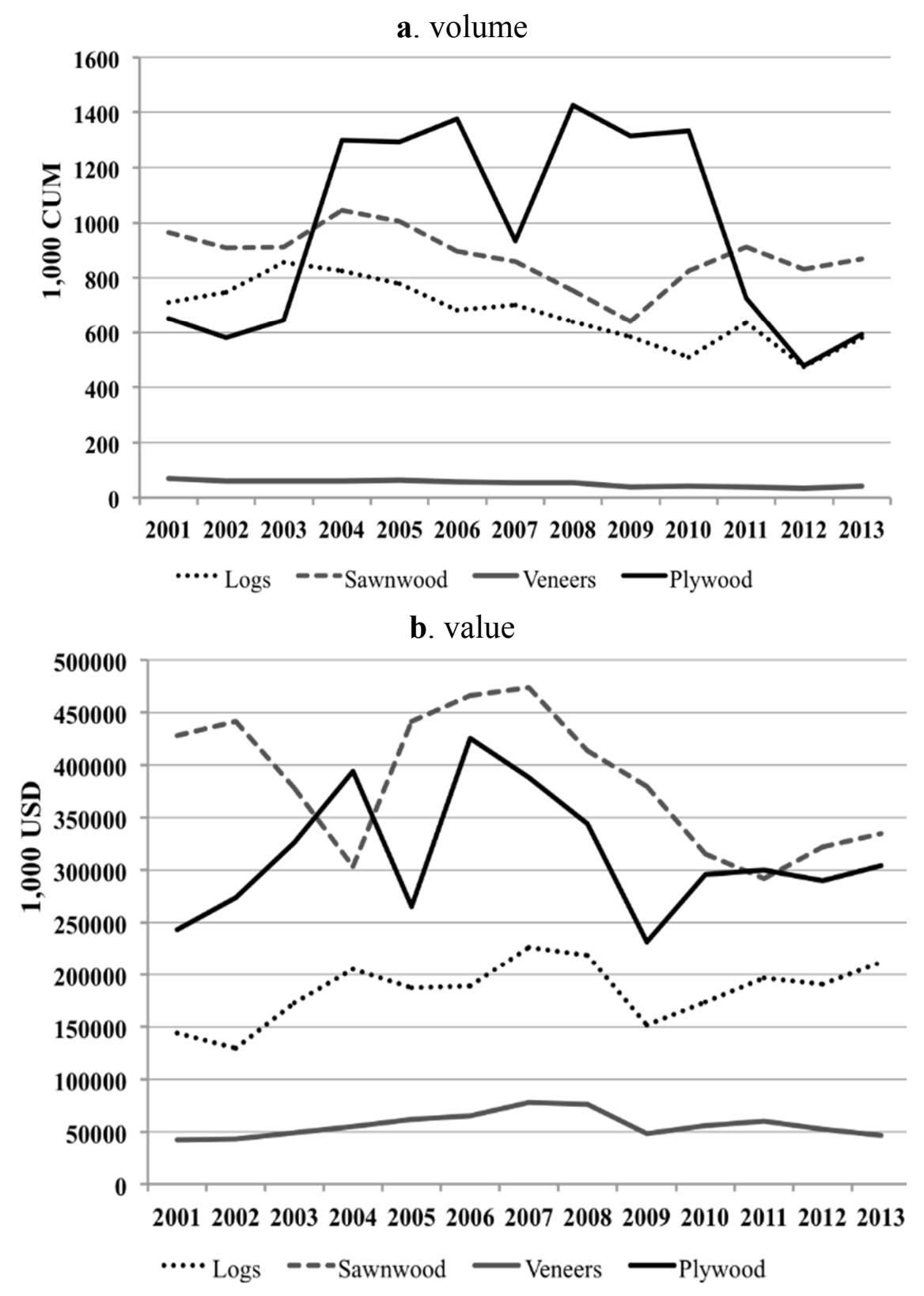

Figure 1. International tropical timber trade - in volume (a) and value (b) - for selected product groups (2001-2013). Source: own elaboration from [43].

\subsubsection{Sawnwood}

Tropical sawnwood trade decreased by $10 \%$ in volume between 2001 and 2013, with a large decrease between 2004 and 2009 (-39\%), followed by a partial recovery in the following years, which made the 2013 traded volumes similar to those observed in 2006-2007 (Figure 1). Traded values also 
decreased overall by about $22 \%$ between 2001 and 2013, with a see-sawing trend: a downturn between 2001 and $2004(-29 \%)$, followed by a recovery up to $2008(+56 \%)$, and then another collapse up to $2011(-38 \%)$. Since then, traded values have slightly increased.

The EU-28 and China were among the largest tropical sawnwood importers worldwide, but while the EU-28 imports decreased over time, Chinese imports increased. This trend is linked to the decreased availability of logs on the international markets and the related lower domestic production of sawnwood in importing countries. For instance, Chinese tropical sawnwood production from imported tropical logs can now meet only one third of the domestic industrial demand [44], pushing up Chinese sawnwood imports. Increased log processing by producing countries (i.e., larger availability of sawnwood) also contributed to this trend.

Trade in sawnwood is now dominated by the Asia-Pacific region: Thailand and Malaysia rank second and third, respectively, in global import statistics, after China. Asian-Pacific timber species like meranti (Shorea spp.) play a major role in international trade. As for other importers, the USA is showing some sign of recovery after 2011, ranking fourth at the global level, while imports by EU countries have remained at a very low level, with just a few exceptions (notably Belgium and Germany).

\subsubsection{Veneer}

Tropical veneer trade decreased in volume between 2001 and $2013(-41 \%)$ and increased in value (about 10\%), with a peak reached in 2007 and a decrease afterwards. In 2013 traded volume totaled about CUM 415,000 with a total value of USD 464 million.

China and Korea were the main importers, followed by France, Italy, and a few other EU countries that mostly depend on African producers (Cameroon, Côte d'Ivoire, and Gabon). Chinese imports, however, were increasingly meeting the growing industrial demand for both the domestic market and re-exports, while the imports of all major importers have diminished their imports during the last three years.

\subsubsection{Plywood}

Global trade in tropical plywood showed a 9\% decrease in volume over the 2001-2013 period, with an upward trend between 2002 and 2007, and a steep decrease (-60\%) starting in 2007-2008 for most tropical plywood products. Conversely, the value of imported plywood increased by $25 \%$ between 2001 and 2013, with a peak in 2006 (about USD 426 million). Japan and the Republic of Korea were the leading importers, importing about $40 \%$ of globally traded plywood, mostly from Indonesia, Malaysia, and China. Imports by the USA decreased by more than half to about $7 \%$ of the global trade over the period 2000-2013, while EU-28 imports remained stable at about 10\%.

The volumetric decline in tropical plywood imports is linked to many factors, including substitution with softwood and temperate hardwood plywood (e.g., birch plywood from Russia or eucalyptus plywood from Brazil) and other panels [24]. Additional effects are due to the introduction of stricter standards on formaldehyde emission levels for imported plywood by key importers such as Japan and the EU [45]. Furthermore, tropical plywood trade has been recently affected by changes in customs tariffs and duties; EU import duties on Malaysian plywood, for example, increased from 3.5\% to 7.0\%. In addition to this, Malaysia recently lost its generalized system of preferences (GSP) tariff status [46]. 


\subsection{Imports by Selected Importers (Total and from VPA Countries)}

Between 2001 and 2013, total tropical timber product imports by selected countries decreased by $38 \%$ in volume and had an $8 \%$ increase in value. When only imports from VPA countries are considered, the data show a $46 \%$ decrease in volume and a $14 \%$ decrease in value over the same period. Differences exist among products and countries; the following sections will describe them in more detail, while Appendix B reports detailed tables of imports by selected countries, both totals and from VPA countries.

Overall, while total volumetric imports by China, India, and Vietnam remained more or less stable over time (with a peak in 2004), imports by Australia, the EU-28, and the USA suffered a clear downturn and halved between 2001 and 2013 (see Table B1 and Figure B1 in Appendix B for more detailed information on total imports (volumes)). Similarly, when only imports from VPA countries are considered, Australia, the EU-28, and the USA decreased their share from $72 \%$ of total imports in 2001 to $54 \%$ in 2013, and China, India, and Vietnam increased from $28 \%$ to $46 \%$ (see Table B2 and Figure B2 in Appendix B for more detailed information on imports from VPA countries (volumes)).

In terms of values, emerging economies doubled the value of their imports, while Australia, the EU-28, and the USA diminished by about one third; as a result, 2013 was the first year where the value of tropical timber imports by China, India, and Vietnam was higher than imports by traditional importers (+USD 240M) (see Figure B3 in Appendix B for more detailed information on total imports (values)). This general trend is also confirmed for imports from VPA countries: emerging economies covered growing import shares in terms of both volumes and values (see Figure B4 in Appendix B for more detailed information on imports from VPA countries (values)). If values are indexed to the same reference year (i.e., 2001) different trends for traditional importers and emerging economies can be noticed, in particular for logs: imports by China, India, and Vietnam increased by $160 \%$, while those by Australia, the EU-28, and the USA diminished by $77 \%$. When analyzing indexed values for imports from VPA countries, trends are similar; they grew by $62 \%$ in the case of China, India, and Vietnam, and decreased by about $45 \%$ in the case of Australia, the EU-28, and the USA (see Figure B5 in Appendix B for more detailed information on total imports (values indexed to 2001)).

\subsubsection{Logs}

On average, total tropical log imports by selected countries decreased by about $17 \%$ in volume and increased by about 63\% in value between 2001 and 2013. The EU-28, Australia, and the USA accounted for the largest part of the reductions ( $-87 \%$ in volume and $-77 \%$ in value), while China imported smaller volumes $(-26 \%)$ but had larger increases in value $(+67 \%)$; India increased both imported volumes $(+279 \%)$ and values $(+459 \%)$ (Figure 2$)$. 
a. volume
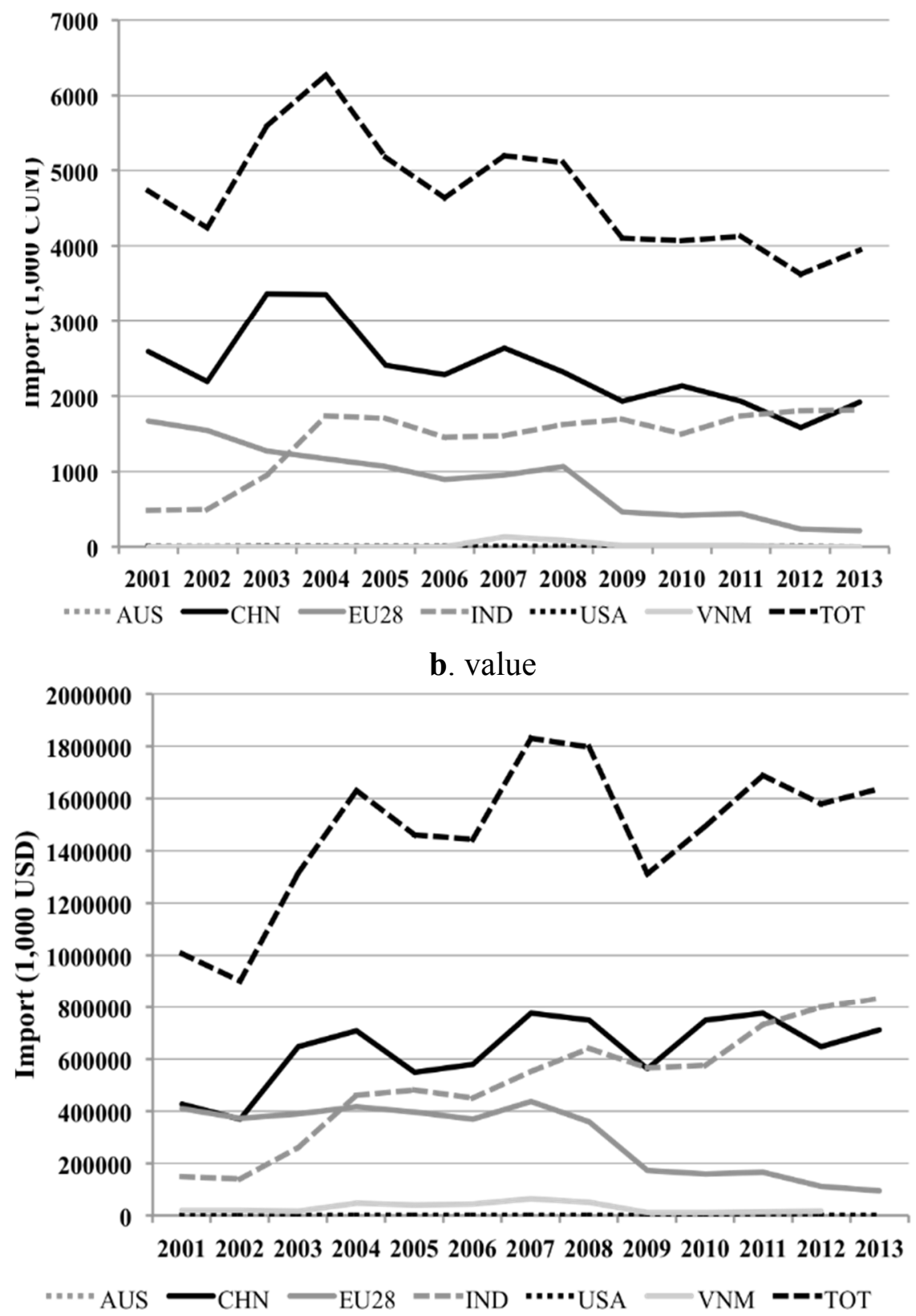

Figure 2. Imports of tropical logs - in volume (a) and value (b) - by selected countries (2001-2013). Source: own elaboration from [43].

Over the same period, the relative incidence of the EU-28, Australia and the USA fell from $41 \%$ to $6 \%$ of total imports versus an increase from $60 \%$ to $94 \%$ of total imports for China, India, and Vietnam.

Log bans implemented in several producing countries (e.g., Gabon) certainly contributed to the volumetric reductions in recent years, albeit log imports persist in the South-South trade flows, in some cases because of difficulties in enforcing those bans. For example, there is evidence that the Vietnamese ban on logs from Laos remains weakly enforced [47].

Reduced availability of large volumes from individual countries also forced importers to diversify their sources. For instance, in 2001, China imported about $72 \%$ of its tropical logs from just two 
countries - i.e., Equatorial Guinea and Gabon - and 93\% of Chinese meranti log imports came from Indonesia and Malaysia. In 2013, four countries (Equatorial Guinea, Papua New Guinea, Myanmar, and the Republic of Congo) represented about $73 \%$ of total Chinese tropical imports, with other five countries (Liberia, Democratic Republic of Congo, Central African Republic, Malaysia, and Cameroon) covering an additional 25\%. India, instead, maintained Myanmar as its chief trade partner, sourcing about $50 \%$ of tropical log imports (mainly teak, Tectona grandis), but the remaining 50\% was imported from a wide range of African (Ghana, Côte d'Ivoire), Latin and Central American (Ecuador, Costa Rica, Panama), and South-East Asian (Malaysia) countries.

The strong downturn in EU-28 imports reflects the critical market conditions in EU countries, decreasing demand from EU timber processors, and changes in investments in processing capacity in African countries. Although this trend is evident in most of the major EU importing countries, France seems to be particularly affected, probably because of its companies' historical presence in the Congo Basin.

Tropical log imports from VPA countries decreased in volume (-42\%) and increased in value (5\%). Again, differences among countries are staggering. Imports by the EU-28 decreased by about $88 \%$ in volume and about 77\% in value between 2001 and 2013; imports by China decreased by 10\% in volume but increased by $119 \%$ in value; while imports by India increased by about $242 \%$ in volume and $464 \%$ in value. Vietnamese log imports from VPA countries increased as well, albeit at a slower pace.

As a consequence, the relative importance of trade partners for VPA countries changed drastically over time: in 2001 the EU-28 imported about 51\% of logs from current VPA countries, while in 2013 it only accounted for $10 \%$, with $90 \%$ being directed to China (73\%) and India (17\%). On average, over the period 2001-2013, the ratio of imported volumes of logs from VPA countries over total imports remained stable at about $22 \%$ for the six selected countries. Yet, dependency on VPA countries varied a lot among selected countries, with the highest values for the EU-28 (about 40\%), and the lowest for the USA (about 1\%).

\subsubsection{Sawnwood}

Total tropical sawnwood imports by selected countries decreased by $29 \%$ in volume and by $5 \%$ in value between 2001 and 2013 (Figure 3). Despite a decrease from 2011 to 2013 (-24\%), Indian imports increased about 20 times between 2001 and 2013. Chinese imports peaked in 2005, then a sudden downturn was observed in the 2006-2009 period, followed by a recovery between 2009 and 2013. The main reasons behind these dynamics included: supply gaps, increasing labor costs, rising domestic sawnwood prices, and the strengthening of the Chinese currency, which affected the competitiveness of tropical sawnwood manufactured in China [44]. 
a. volume
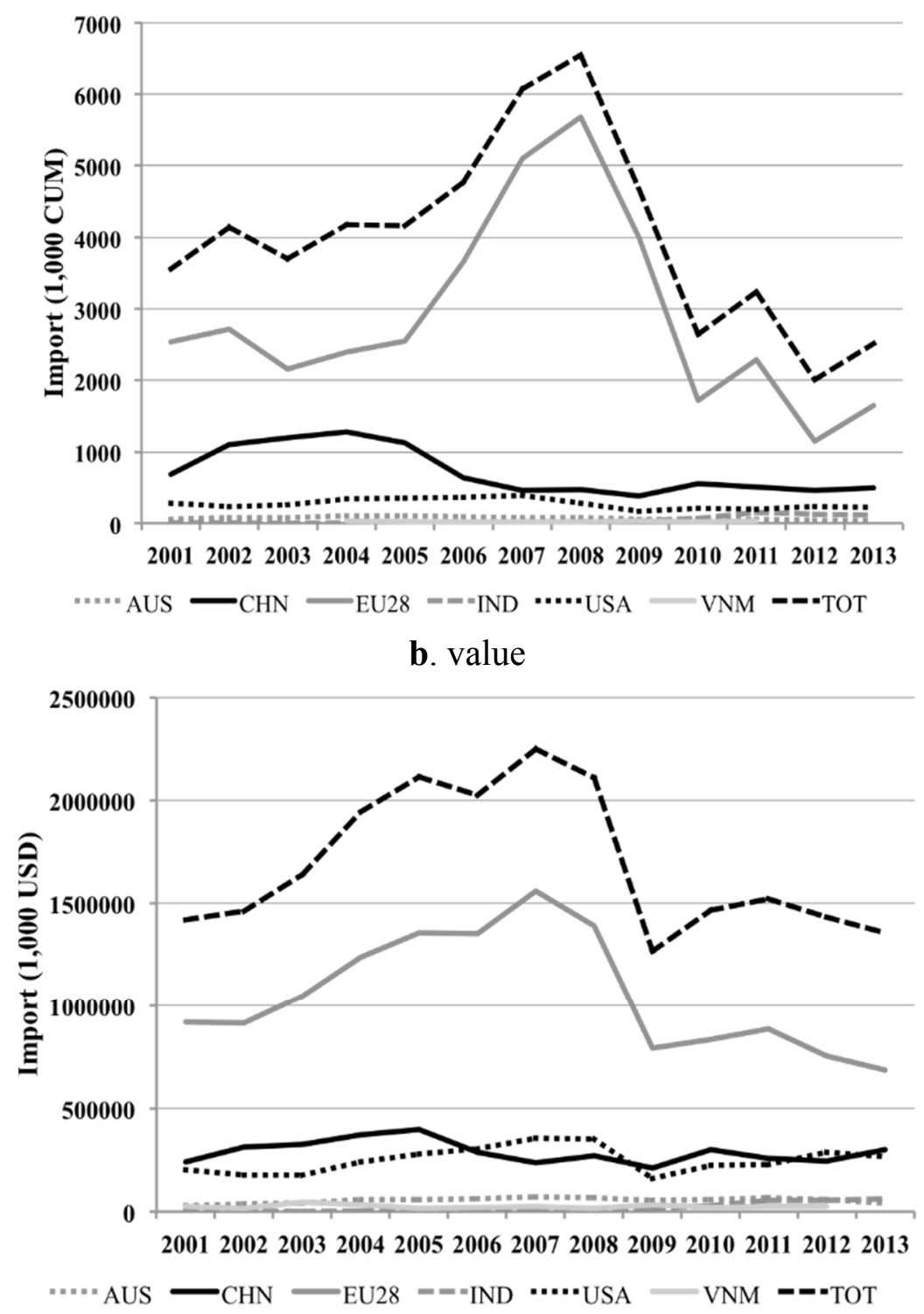

Figure 3. Imports of tropical sawnwood - in volume (a) and value (b) - by selected countries (2001-2013). Source: own elaboration from [43].

The EU-28 and the USA have similar profiles determined largely by the financial crisis. Their imports increased to a peak until 2007-2008 and then went down, with a $-83 \%$ variation in the case of the EU-28 and $-33 \%$ in the USA. Despite the decreasing trend, the EU-28 still remains the largest tropical sawnwood importer within the selected group of countries, covering more than $65 \%$ of total volumetric imports, down from about $90 \%$ in 2000 .

In terms of relative incidence, China, India, and Vietnam covered about $19 \%$ of total tropical sawnwood volumes (and 19\% of value too) imported by selected countries in 2001, while they covered $24 \%$ of volumes and $27 \%$ of value in 2013 . Although the trend is less evident compared to that observed for tropical logs, it is quite clear that - in terms of imported quantities and values - the relative importance of traditional importers such as Australia, the EU-28, and the USA diminished, while that of emerging economies such as China, India, and Vietnam increased. 
On average, VPA countries provided about $40 \%$ of total tropical sawnwood imports by selected countries, with China (45\%), Australia (39\%), and the EU-28 (34\%) showing the highest import dependencies. As of 2013, two countries, Cameroon (52\%) and Indonesia (30\%), were the source of about $82 \%$ of total sawnwood imports by the selected importers. These countries were also China's main partners in 2013 , covering about $82 \%$ of total Chinese tropical sawnwood imports. Cameroon was also the largest supplier of tropical sawnwood to the EU-28 (61\%), followed by Indonesia (23\%) and the Republic of Congo (11\%). Although market destinations for Africa's tropical sawnwood exports have expanded, exporters remain strongly dependent on EU markets and have therefore suffered the impacts of the economic crisis on demand, especially in the building sector.

\subsubsection{Veneer}

Total tropical veneer imports by selected countries had a negligible decrease in volume between 2001 and 2013. The EU-28 and India were the only importers showing positive variations, although with different profiles: EU-28 imports decreased starting from 2007 to 2008, while Indian imports grew continuously over the period with a further increase from 2010 (Figure 4). Veneer imports decreased in terms of value $(-5 \%)$ and India was the only country showing a clear positive variation between 2001 and 2013, while all other countries showed a negative trend. As a result, between 2000 and 2013 Australia, the EU-28, and the USA had an aggregated positive variation $(+22 \%)$ in term of volume, albeit largely influenced by the performance of the EU-28 and an $8 \%$ decrease in terms of value. China, India, and Vietnam altogether decreased their imports in terms of both volume (-39\%) and value $(-25 \%)$.

According to [44], the recently declining EU veneer imports reflect a long-term weakness in the European plywood and veneer industries, with consumption diminishing in nearly all major European markets over the past 15 years. The introduction of alternative materials (e.g., plastics, laminates) has further contributed to this negative trend.

The proportion of imports by Australia, the EU-28, and the USA on total imports by selected countries increased until 2007 (94\%) and then decreased to 78\%, while China, India, and Vietnam increased their relative role, reaching shares already observed in 2002 (21\%-22\%). As already mentioned, this is mostly due to the role of India, while China showed a negative trend for veneer imports; this may be because, in recent years, most of China's tropical veneer has been produced domestically from imported tropical logs [46].

Veneer imports from VPA countries represented about $22 \%$ of total imports by selected countries. The EU-28 remained by far the main importer, receiving about $88 \%$ of VPA countries' exports to selected countries, down from the highest peak reached in 2008 (96\%), with China coming second. In 2013, about 50\% of total veneer imports originating from VPA countries were from Cameroon, with the Republic of the Congo providing another $27 \%$ and Indonesia and Ghana almost equally covering the remaining proportion. 
a. volume
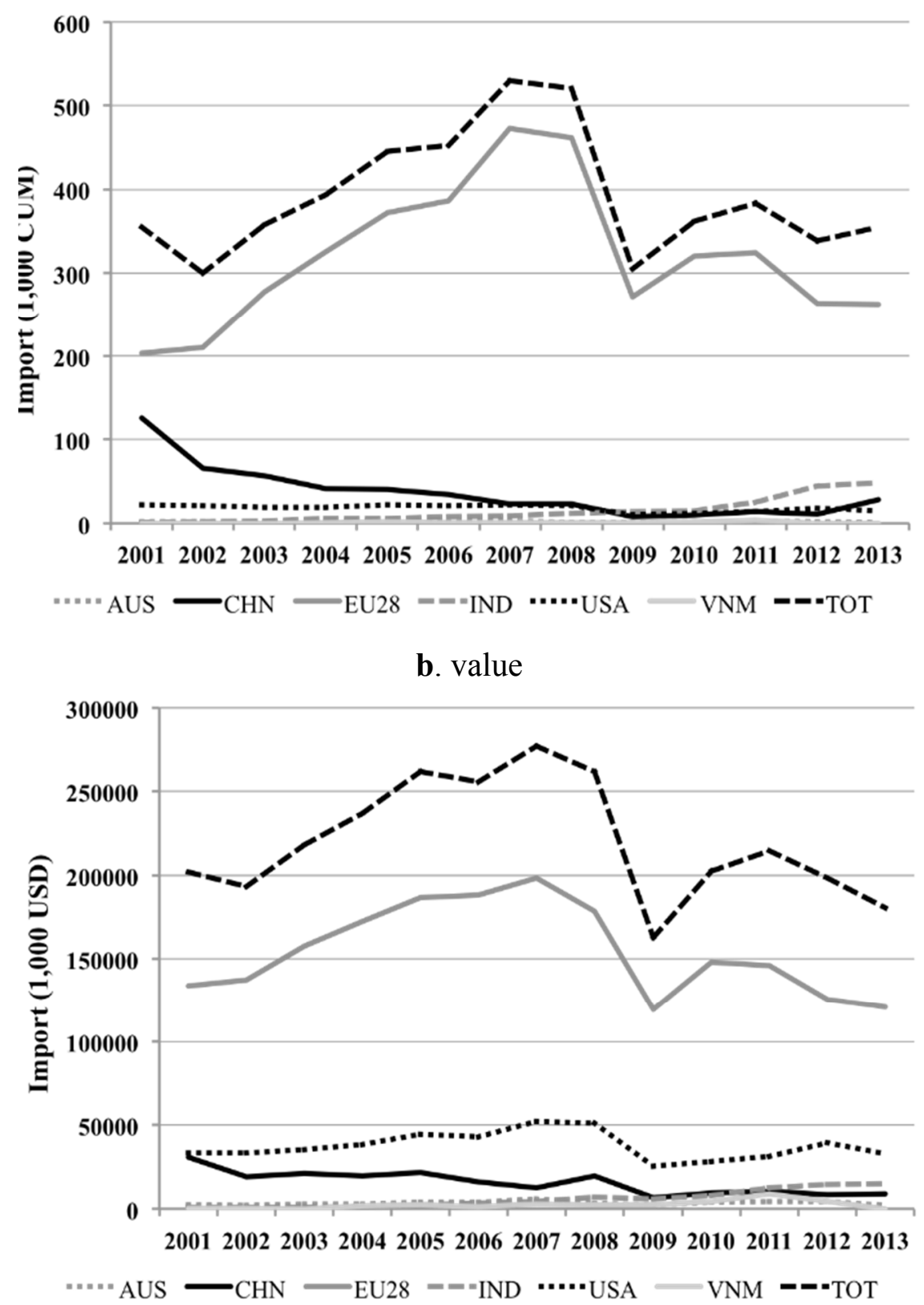

Figure 4. Imports of tropical veneers - in volume (a) and value (b) — by selected countries (2001-2013). Source: own elaboration from [43].

\subsubsection{Plywood}

Total tropical plywood imports by selected countries halved diminished $(-52 \%)$ in volume and decreased by about one third (-34\%) in value between 2001 and 2013 (Figure 5). All countries—with the exception of India - decreased both imported volumes and values. China, India, and Vietnam altogether suffered the same drop in terms of value $(-34 \%)$ and a similar one in terms of volume (-54\%) compared to Australia, the EU-28, and the USA (-52\%). The downturn in American imports ( $-65 \%$ in volume, $27 \%$ in value) was strongly affected by the declining trend in the building sector as well as other factors, including the anti-dumping and countervailing duty investigations of imports of 
hardwood and decorative plywood from China by the U.S. Department of Commerce (2012) and the increasing role of green building certification under the U.S. Green Building Council's Leadership in Energy and Environmental Design (LEED) standards, which might make the tracking of supply chains for tropical products difficult.

a. volume
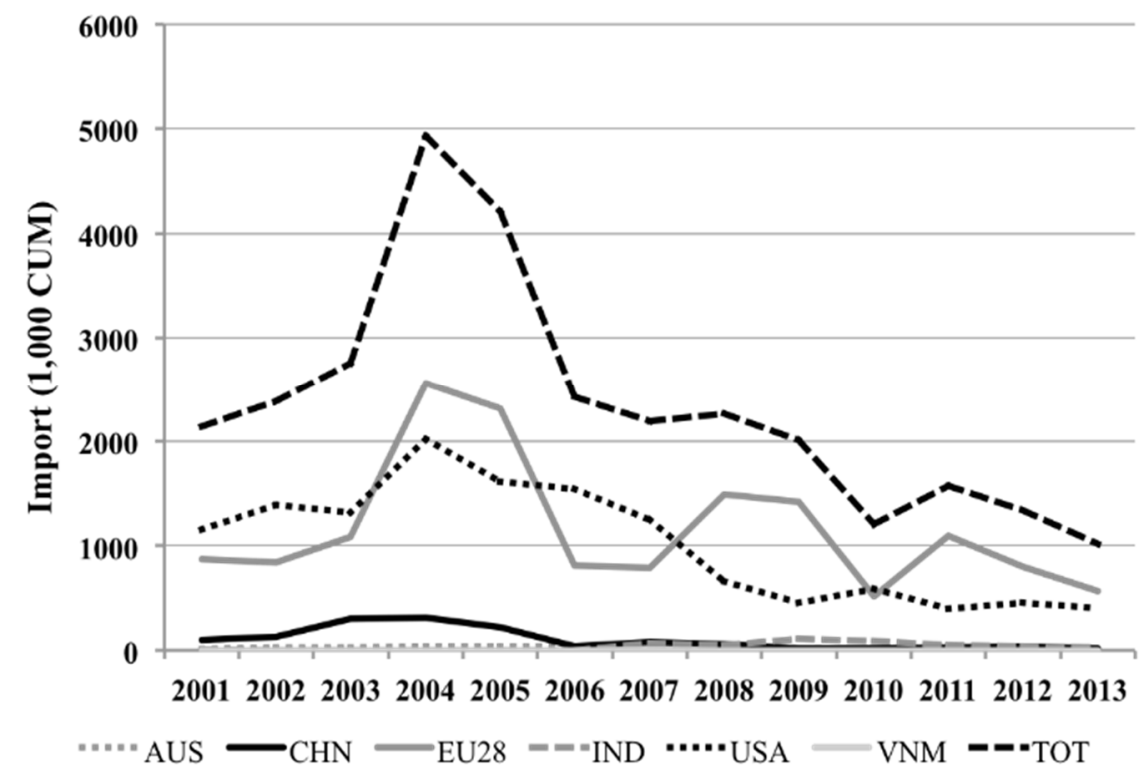

b. value

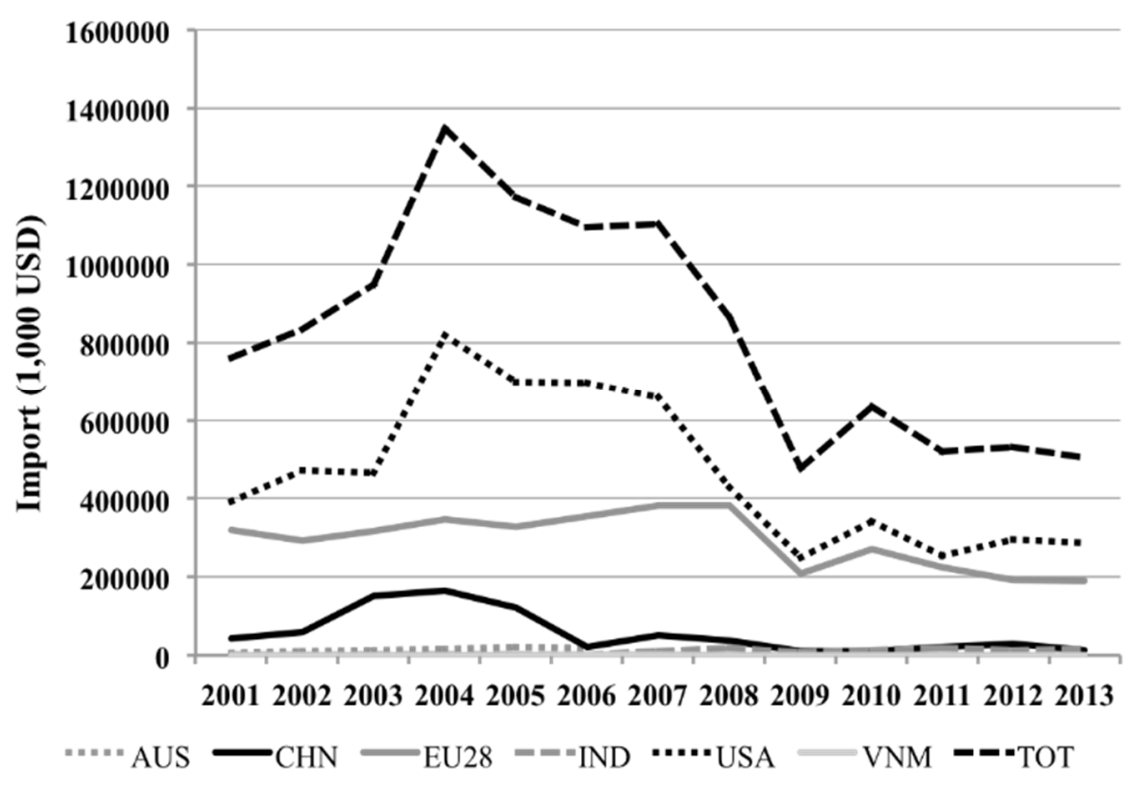

Figure 5. Imports of tropical plywood - in volume (a) and value (b) — by selected countries (2001-2013). Source: own elaboration from [43].

The declining import trend ( $-35 \%$ in volume) in the EU-28 may be linked to several factors ranging from the building sector crisis to the confirmation of EU anti-dumping duties on okoumé (Aucoumea klaineana) plywood from China. The drop in Chinese plywood imports is instead linked to an increased domestic production capacity, with an industry based on imported tropical hardwood logs 
(for face veneers) and other log supplies for cores [48]; about $83 \%$ of Chinese plywood production is intended for the domestic market, while the remainder is exported [49].

The EU-28 and the USA account for about 95\% of total imports by selected countries, with China and India covering the remaining 5\%; basically no significant change in relative proportions occurred between 2001 and 2013.

Tropical plywood imports from VPA countries covered about 30\% in volume of total tropical plywood imports by selected countries, down from 50\% in 2001-2002. In absolute values, plywood imports decreased from about CUM 1.2 million in 2001 to CUM 0.3 million in 2013 (-74\%). The USA (70\%) and EU-28 (25\%) were the main importers within the group, but China and Australia were the countries with the highest dependency on imports originating in VPA countries. Among VPA countries, Indonesia dominated exports towards the selected importers, representing about $98 \%$ of total imported volumes as of 2013, a figure that is not surprising given that, together with Malaysia, Indonesia was the main tropical plywood exporter worldwide.

\section{Discussion}

While total volumetric imports by China, India, and Vietnam remained more or less stable over time, imports by Australia, the EU-28, and the USA suffered a clear downturn. In recent years, tropical timber imports by the former group of countries have been higher than imports by traditional Northern importers, reaching a difference in terms of imported volumes of about CUM 1.1 million in 2013. When only imports from VPA countries are considered, the former group of countries decreased imports by $10 \%$ in volume and increased by $62 \%$ in value, while the latter decreased by $60 \%$ in volume and $34 \%$ in value.

The decline started before the global financial crisis in 2008, and became particularly intense thereafter, with relative annual variations that were quite strong in 2008-2010 and 2011-2012. As a consequence, in terms of total imports, the ratio of imports by emerging economies relative to total imports doubled: from about $37 \%$ of total imports in 2001 to $57 \%$ in 2013 . Similarly, when only imports from VPA countries are considered, Australia, the EU-28, and the USA decreased their share between 2001 and 2013 and China, India, and Vietnam increased from 28\% to 46\%. These findings corroborate other recent studies (e.g., [50,51]) and indicate that the shift in trade patterns of tropical timber products may be ascribed predominantly to the economic crisis, which hit timber consumption more in Northern countries. The EU share of tropical timber imports over total timber imports, for example, was already declining before the adoption of the FLEGT Action Plan and the implementation of the EUTR [23].

The results also indicate that, while exports from tropical timber-producing countries decreased over the period 2001-2013, at least part of those exports shifted from historical Northern destinations to emerging markets with sustained demands. The latter assured continuity of purchases and the value of their imports doubled (with a corresponding decrease of about 30\% in value by Australia, the EU-28, and the USA).

Yet, the substantial and negative impacts on consumption may partly shade other factors that could be having an impact - albeit still limited due to their recent implementation — on international trade, such as the markets' reaction to the widely announced introduction of measures to reduce the illegal 
timber trade, the changes in the forestry sectors of tropical timber-producing countries, especially VPA ones, or the ongoing substitution of tropical species with temperate hardwood ones.

For instance, the results indicate that imports from VPA countries might have been able to withstand the downturn better than other tropical timber-producing countries, achieving a larger share of total tropical imports in recent years. It is of course premature to wholly ascribe such better "resistance" to the preparatory measures that VPA countries have been adopting and implementing over the course of the last decade (e.g., increased readiness of the government to react to crises with ad hoc measures), but given the general level of engagement, participation, and communication from both the public and private sectors in many VPA countries, we argue that such a role should not be readily discounted. For example, the governments of both Cameroon and the Republic of Congo readily met over the course of the financial crisis to discuss, and later adopt and implement, concerted financial measures (e.g., lowering of annual forestry levies, relaxation of export quotas, lowering of export taxes, etc.) to allow logging companies to better withstand the crisis. These measures, together with the Gabonese log export ban, contributed to support roundwood exports [52]. The same did not happen, for instance, in the second half of the 1990s, when the Asian crisis badly hit the timber sector in the region.

A positive spin-off from so many years of VPA preparations and discussions in producing countries could also have indirectly favored a shift in the destination of "better" timber (e.g., better controls and verifications in preparation to the issuance of FLEGT licenses), albeit not yet claimed as "legal" by the issuing of FLEGT licenses, and to emerging economies, as they imported an increasing share of total tropical imports from VPA countries in both volumes and values (from $21 \%$ of total value of imports in 2001 to $40 \%$ in 2013 ).

Of course, the mainstream thinking about a shift in exports to less demanding markets, induced by stricter requirement in Northern countries, is still a possibility (e.g., [24]), and it could represent at least part of the shifts indicated by the results. In particular, although our results do not consider the size of the enterprises exporting timber from VPA countries or of those importing into final consumer markets, there is evidence of enterprise concentration. This may occur because small and medium companies in producing and importing countries might not be equipped with the resources to set up traceability or complex due diligence systems (DDS). Exporting companies may decide either to stop exporting to markets with stricter legality requirements, and thus divert their production to less demanding markets, or to sell their products to bigger exporters. In a similar way, small and medium importers in consumer countries might not be able to run a DDS - or any other equivalent system and thus be induced to stop importing tropical timber, reduce the number of imported species and suppliers, or simply buy from bigger importers [52]. For example, Jonsson et al. [23] indicated that during a pilot test ConLegno's (The Consorzio Servizi Legno Sughero) was one of the two first monitoring organizations recognized by the European Commission in 2013 for the purposes of EUTR requirements). In Italy, three companies with potentially high-risk suppliers were audited. One of them reported a significant decrease - from 120 to 25 - in the number of wood species imported during the last year. The decline in the number of species was attributed by the company to the high cost of implementing the DDS procedures, which compelled it to focus on fewer species and consolidate trade relationships with some of its suppliers. 


\section{Conclusions}

Total imports of tropical primary timber products diminished between 2001 and 2013. Different trends apply to different importers: trade flows with traditional importers such as Australia, the EU, and the USA decreased, while those of emerging economies such as China, India, and Vietnam increased. Confirming other studies [23], our results indicate that tropical timber has managed to uphold its market share in Northern markets better in value terms than in volumetric terms, which could be taken as an indication of more value-added (i.e., processed) tropical timber imports. In addition to this, specific analyses on a selected set of products suggest that there might be some diversion, i.e., a shift of tropical timber products from traditional importers towards emerging economies. Without being conclusive, this might be occurring due to the lower standards of their import regulations or the increased standards of Northern countries implementing legality-related measures. This trend is confirmed with regards to imports from VPA countries. Diversion seems quite clear in the case of industrial roundwood (logs) while it is less evident in the case of sawnwood and not perceivable for veneers and plywood.

There are many driving forces behind this trend, including, for example, changes in trade patterns induced by the 2008 financial crisis and the related decline in many sectors, such as housing and building in general, but also the increasing domestic demand for timber products by growing proportions of the Chinese and Indian populations with rising incomes. In the case of logs, an additional factor is represented by export bans adopted in some producing countries.

Although there is some preliminary evidence in the literature, isolating the effects of policy measures such as the FLEGT Action Plan, the EUTR, the Lacey Act, and the Australian Illegal Logging Prohibition Act on global timber trade patterns is not an easy task. While a growing proportion of imports by China and India are intended for domestic consumption, large amounts are processed and then re-exported into the EU and the USA. They will therefore remain subject to normative requirements asking for legality of origin in the countries of final destination. Long and complicated supply chains, including trade via third countries [53], can make information gathering and assessment very problematic, expensive, or sometimes not feasible. Yet, global timber trade will have to adapt to legality-related regulations in the future and a focus on tropical timber-producing countries, as is the case with the VPAs, still seems the best option to try and reduce costs and complexity at the source of the supply chain.

Findings also indicate that we are probably facing more than the development of a simple dual market. On the one hand, there exists a channel of legal tropical timber exports oriented towards Northern countries versus a channel of non-legally qualified timber exports-i.e., material that does not have full and systematic evidence about its legal source/status - towards emerging economies. Yet, on the other hand, there is the development of a new, growing, and potentially predominant South-South trade flow for many tropical wood products. This includes the emergence of large domestic and regional markets that in many cases include illegal and informal chainsaw lumber markets, especially in Central Africa [54-57].

While this paper sheds some light on the recent trends in the global tropical timber trade, more research is needed to better understand the technical and political complexities introduced into the system by an ever-evolving legal framework. All current initiatives tackling the illegal trade in timber 
products, albeit implemented by different countries in different ways, have been adopted with the common objective of reducing the negative environmental, social, and economic impacts to which illegal logging contributes. Thus, further research is not only warranted on trade trends, but also on how such trends reflects better forest conditions on the ground, and on how they might be impacted by innovative regulatory measures that go beyond standard public policies, and embrace a mix of public and private measures (including forest certification, legality verification and financing, and investment in the forestry sector).

\section{Acknowledgements}

The research was conducted with the financial support of the UKAID-funded KnowFOR (Forestry Knowledge) program and the CGIAR Research Program on Forests, Trees, and Agroforestry (FTA). The authors would like to thank the StarTree project staff, in particular Enrico Vidale and Riccardo da Re (TESAF Department, University of Padova) for their valuable support in analyzing and cleaning the data collected for the purposes of the research. The authors would like to thank Spartak Koci for support in the first drafting of the methodology used and the three anonymous reviewers for their valuable comments on a previous version of this paper.

\section{Author Contributions}

All authors contributed equally to this work.

\section{Conflicts of Interest}

The authors declare no conflict of interest.

\section{Appendix}

\section{A. Detailed Procedures Used for Data Cleaning and Elaboration}

\section{A.1. Data Shortcomings and Double Flow Reporting}

The comparison of imported and exported commodity quantities often reveals data shortcomings; in several cases the same trade flow is reported in a different amount by the importing and exporting country. Insurance, freight, and other costs cannot explain the detected differences for physical quantities. A potential reason behind these gaps could be different reporting thresholds in different countries. Normally, reported import data are considered more reliable because tariffs and taxes are usually imposed on imports, and hence countries should have a strong interest in the best possible import recording [58].

In many cases, double-flow reporting was detected. This occurs when the same trade flows are reported by two customs authorities, one by the exporting country and the other by the importing one. In theory, every country should record and report trade flows entering and leaving its national boundaries; as a consequence, we should expect to find corresponding or similar records reported by both trade partners. Nonetheless, it is quite rare to have this information due to the lack of reporting. In most cases only one of the trade partners, either the exporter or the importer, reported the trade information. In those cases, the "mirroring data" technique was adopted and we reconstructed trade 
flows on the basis of data reported by partner countries [58]. Although we are aware that, in principle, data from mirror statistics are less reliable than direct data, mirroring techniques represent a second-best option for cases when data are missing.

Sometimes both trade partners report the same trade flow, but quantities and/or values differ. There might be several reasons behind these differences, including valuation, i.e., imports are recorded as "cost, insurance and freight" (CIF) and exports as "free on board" (FOB). In such cases the approach used-after testing different solutions - was to choose the higher of the two corresponding records. Based on tests performed by the StarTree Project team [59], this allows standard deviation for values and standard error for estimated quantities to be reduced.

\section{A.2. Outliers}

The presence of outliers among gathered data is a common issue. As a general approach, values and quantities were left untouched, but evident outliers were identified and either recalculated or dropped. In order to identify potential outliers, time series for annually traded quantities and values for each commodity were elaborated and plotted. When evident outliers were found, they were further investigated in order to find a reliable explanation or recalculate them. In particular, the following approaches were used, in order of priority given:

- searching for alternative data sources (i.e., normally FAOSTAT database or the import/export country's statistical agency or portal);

- if an outlier belonged to a "double-flow record," it was substituted with the value declared by the deleted partner (only if this corrected the value);

- after elaborating the time series between the two trade partners, we estimated the corrected value through the linear price trends;

- computing of average figure between the trade value of the previous and following year between the same trade partners;

- data were dropped.

\section{A.3. Missing Data}

Missing quantities mostly refer to those records having "unit" variable equal to " 1 ." In this case, it was assumed that a trade-flow exists, and quantities were estimated based on average prices. Instead, other anomalous quantities (e.g., very low amounts, such as $1 \mathrm{~kg}$ ) were not modified-even though they might include errors - as data reliability thresholds were not known a priori.

Missing prices were computed per commodity, year, and quantity. To estimate the missing weights or volumes, price per unit of weight or volume was calculated for those records where quantities were reported.

\section{A.4. Conversion Factors and Inconsistent Units}

The physical values of the commodity groups reported by the UN COMTRADE database are recorded in different units. In order to allow the aggregation of the traded volume of timber and timber products, the original units were converted into a common unit (depending on the commodity group). 
In most cases, available data referred to mass values, but in some cases volumes were also reported (CUM or even liters). For plywood data were sometimes also presented in terms of surface $\left(\mathrm{m}^{2}\right)$. UN COMTRADE data do not always report (appropriate) physical quantities; in these cases trade in weight unit or CUM was estimated on the basis of the monetary values. The following conversion factors were used [44]:

- non-coniferous tropical logs: 1.37 CUM/ton,

- non-coniferous tropical sawnwood: $1.43 \mathrm{CUM} /$ ton,

- tropical veneer: $1.33 \mathrm{CUM} /$ ton,

- tropical plywood: $1.54 \mathrm{CUM} /$ ton.

\section{B. Detailed Results}

Table B1. Tropical timber product imports by selected countries, 2001 and 2013.

\begin{tabular}{|c|c|c|c|c|c|c|c|c|c|c|}
\hline \multirow{2}{*}{ Country } & \multicolumn{4}{|c|}{2001} & \multicolumn{4}{|c|}{2013} & \multicolumn{2}{|c|}{$\begin{array}{c}2001-2013 \\
\% \text { Variation }\end{array}$} \\
\hline & $\begin{array}{l}\text { Volume } \\
\text { (CUM) }\end{array}$ & $\%$ on $\mathrm{T}$ & $\begin{array}{c}\text { Value } \\
\text { (1000 USD) }\end{array}$ & $\%$ on $\mathrm{T}$ & $\begin{array}{l}\text { Volume } \\
\text { (CUM) }\end{array}$ & $\%$ on $\mathrm{T}$ & $\begin{array}{c}\text { Value } \\
\text { (1000 USD) }\end{array}$ & $\%$ on $\mathrm{T}$ & Volume & Value \\
\hline Australia & 74,539 & 0.7 & 36,432 & 1.4 & 36,056 & 0.5 & 4,3043 & 1.2 & -51.6 & 18.1 \\
\hline EU-28 & $5,273,893$ & 48.8 & $1,783,218$ & 54.0 & $2,690,886$ & 34.3 & $1,088,960$ & 29.6 & -49.0 & -38.9 \\
\hline USA & $1,458,811$ & 13.5 & 631,438 & 19.4 & 641,192 & 8.2 & 586,832 & 16.0 & -56.0 & -7.1 \\
\hline a. Sub-Total 1 & $6,807,243$ & 63.0 & $2,451,088$ & 74.8 & $3,368,135$ & 42.9 & $1,718,835$ & 46.7 & -50.5 & -29.9 \\
\hline China & $3,496,595$ & 32.4 & 741,297 & 21.2 & $2,457,090$ & 31.3 & $1,033,272$ & 28.1 & -29.7 & 39.4 \\
\hline India & 489,585 & 4.5 & 152,420 & 3.8 & $2,015,226$ & 25.7 & 925,283 & 25.2 & 311.6 & 507.1 \\
\hline Vietnam & 4,884 & 0 & 44,579 & 0.2 & $5,756^{(a)}$ & 0.1 & 0 & 0 & 17.8 & -100.0 \\
\hline b. Sub-Total 2 & $3,991,064$ & 37.0 & 938,296 & 25.2 & $4,478,072$ & 57.1 & $1,958,554$ & 53.3 & 12.2 & 108.7 \\
\hline $\begin{array}{c}\text { Total } \\
(\mathrm{T}=\mathrm{a}+\mathrm{b})\end{array}$ & $10,798,307$ & 100.0 & $3,389,385$ & 100.0 & $7,846,206$ & 100.0 & $3,677,390$ & 100.0 & -27.3 & 8.5 \\
\hline
\end{tabular}

(a) Data only refer to 4412. Source: own elaboration from [43].

Table B2. Tropical timber product imports by selected countries from VPA countries, 2001 and 2013.

\begin{tabular}{|c|c|c|c|c|c|c|c|c|c|c|}
\hline \multirow{2}{*}{ Country } & \multicolumn{4}{|c|}{2001} & \multicolumn{4}{|c|}{2013} & \multicolumn{2}{|c|}{$\begin{array}{c}\text { 2001-2013 } \\
\text { \% Variation }\end{array}$} \\
\hline & $\begin{array}{l}\text { Volume } \\
\text { (CUM) }\end{array}$ & $\%$ on $\mathrm{T}$ & $\begin{array}{c}\text { Value } \\
\text { (1000 USD) }\end{array}$ & $\%$ on $\mathrm{T}$ & $\begin{array}{l}\text { Volume } \\
\text { (CUM) }\end{array}$ & $\%$ on $\mathrm{T}$ & $\begin{array}{c}\text { Value } \\
\text { (1000 USD) }\end{array}$ & $\%$ on $\mathrm{T}$ & Volume & Value \\
\hline Australia & 16,920 & 0.4 & 8,053 & 0.6 & 11,989 & 0.5 & 18,826 & 1.6 & -29.1 & 133.8 \\
\hline EU-28 & $2,411,550$ & 57.3 & 809,335 & 61.0 & 935,038 & 41.0 & 433,581 & 37.9 & -61.2 & -46.4 \\
\hline USA & 596,655 & 14.2 & 226,767 & 17.1 & 275,122 & 12.1 & 232,780 & 20.3 & -53.9 & 2.7 \\
\hline a. Sub-Total 1 & $3,025,125$ & 71.9 & $1,044,154$ & 78.7 & $1,222,149$ & 53.6 & 685,187 & 59.9 & -59.6 & -34.4 \\
\hline China & $1,135,738$ & 27.0 & 265,524 & 20.0 & 875,238 & 38.4 & 376,276 & 32.9 & -22.9 & 41.7 \\
\hline India & 44,768 & 1.1 & 11,069 & 0.8 & 184,764 & 8.1 & 82,604 & 7.2 & 312.7 & 646.2 \\
\hline Vietnam & $7^{\text {(a) }}$ & 0 & 5,969 & 0.4 & 0 & 0 & 0 & 0 & -100.0 & -100.0 \\
\hline
\end{tabular}


Table B2. Cont.

\begin{tabular}{|c|c|c|c|c|c|c|c|c|c|c|}
\hline \multirow{2}{*}{ Country } & \multicolumn{4}{|c|}{2001} & \multicolumn{4}{|c|}{2013} & \multicolumn{2}{|c|}{$\begin{array}{c}2001-2013 \\
\% \text { Variation } \\
\end{array}$} \\
\hline & $\begin{array}{l}\text { Volume } \\
\text { (CUM) }\end{array}$ & $\%$ on $\mathrm{T}$ & $\begin{array}{c}\text { Value } \\
\text { (1000 USD) }\end{array}$ & $\%$ on $\mathrm{T}$ & $\begin{array}{l}\text { Volume } \\
\text { (CUM) }\end{array}$ & $\%$ on $\mathrm{T}$ & $\begin{array}{c}\text { Value } \\
\text { (1000 USD) }\end{array}$ & $\%$ on $\mathrm{T}$ & Volume & Value \\
\hline Vietnam & $7^{\text {(a) }}$ & 0 & 5,969 & 0.4 & 0 & 0 & 0 & 0 & -100.0 & -100.0 \\
\hline b. Sub-Total 2 & $1,180,513$ & 28.1 & 282,562 & 21.3 & $1,060,002$ & 46.4 & 458,879 & 40.1 & -10.2 & 62.4 \\
\hline $\operatorname{Total}(\mathrm{T}=\mathrm{a}+\mathrm{b})$ & $4,205,638$ & 100.0 & $1,326,717$ & 100.0 & $2,282,151$ & 100.0 & $1,144,066$ & 100.0 & -45.7 & -13.8 \\
\hline
\end{tabular}

a. volume

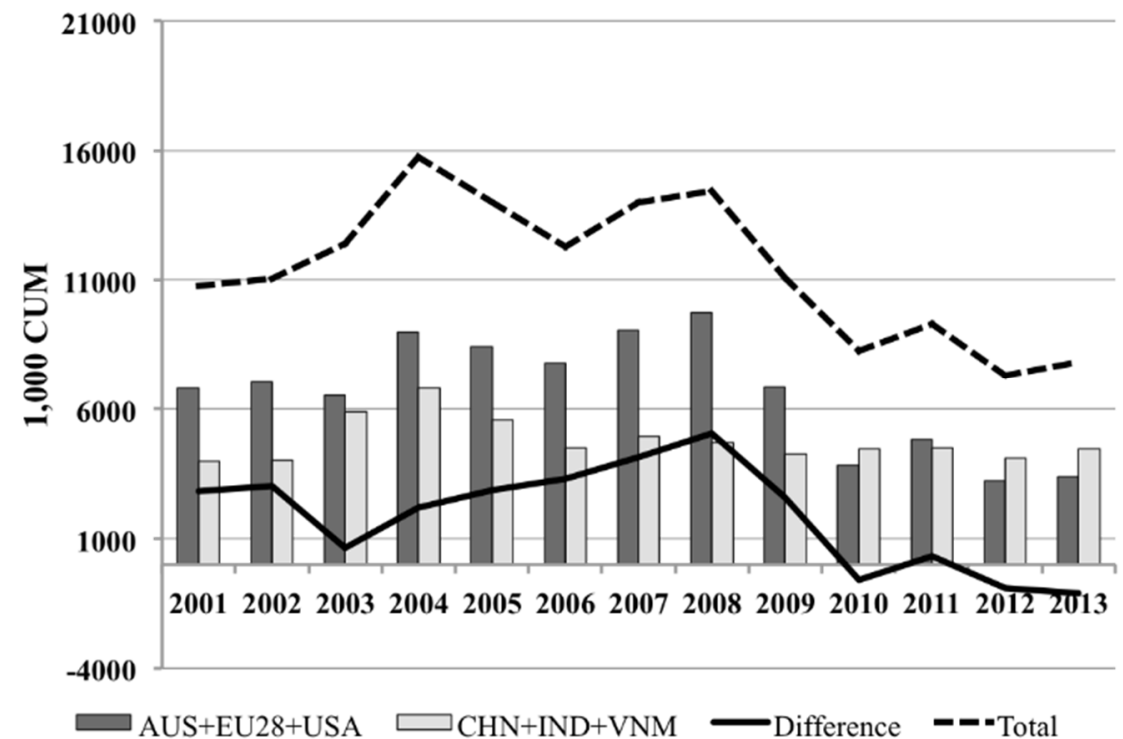

b. value

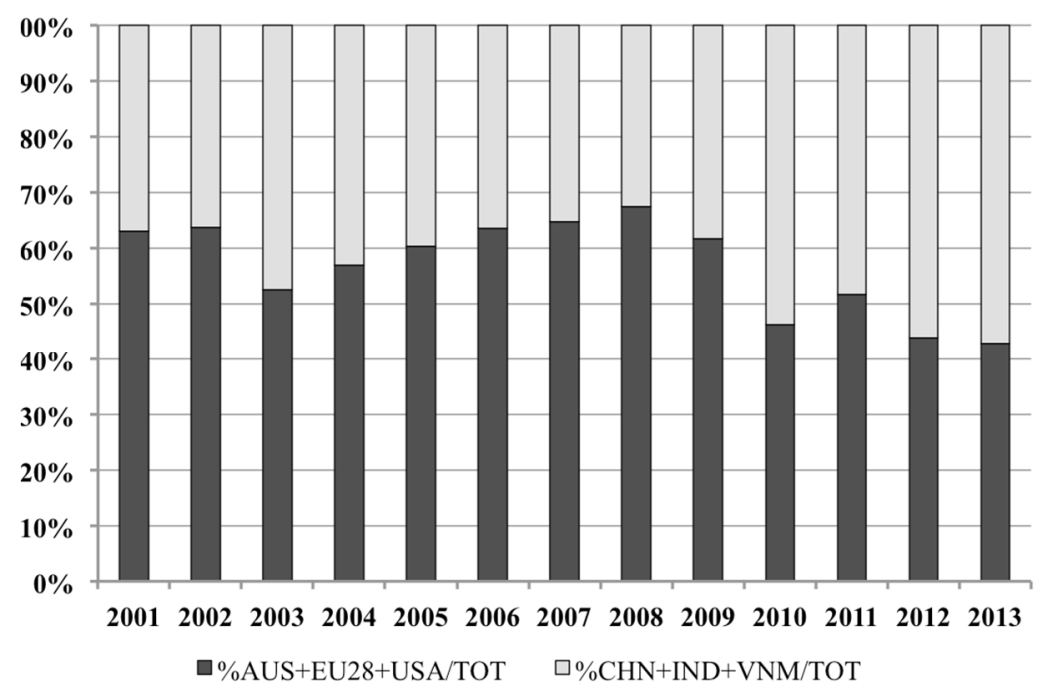

Figure B1. (a) Tropical timber product imports by groups of selected countries, in volume; and (b) \% incidence of selected countries on total imports (2001-2013). AUS = Australia; $\mathrm{CHN}=$ China; EU-28 = European Union; IND = India; USA = United States of America; $\mathrm{VNM}=$ Vietnam. Difference means difference between (AUS + EU-28 + USA) and $(\mathrm{CHN}+\mathrm{IND}+\mathrm{VNM})$. Source: own elaboration from [43]. 
a. volume

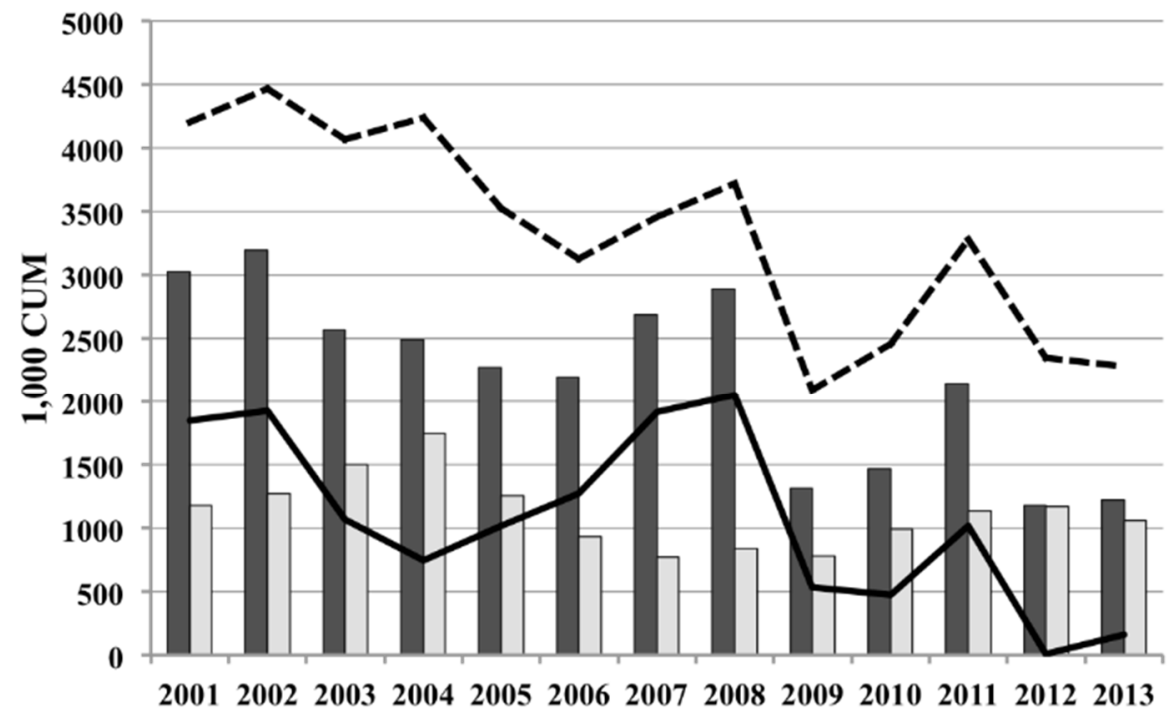

AUS+EU28+USA $\square$ CHN+IND+VNM -Difference ---Total

b. value

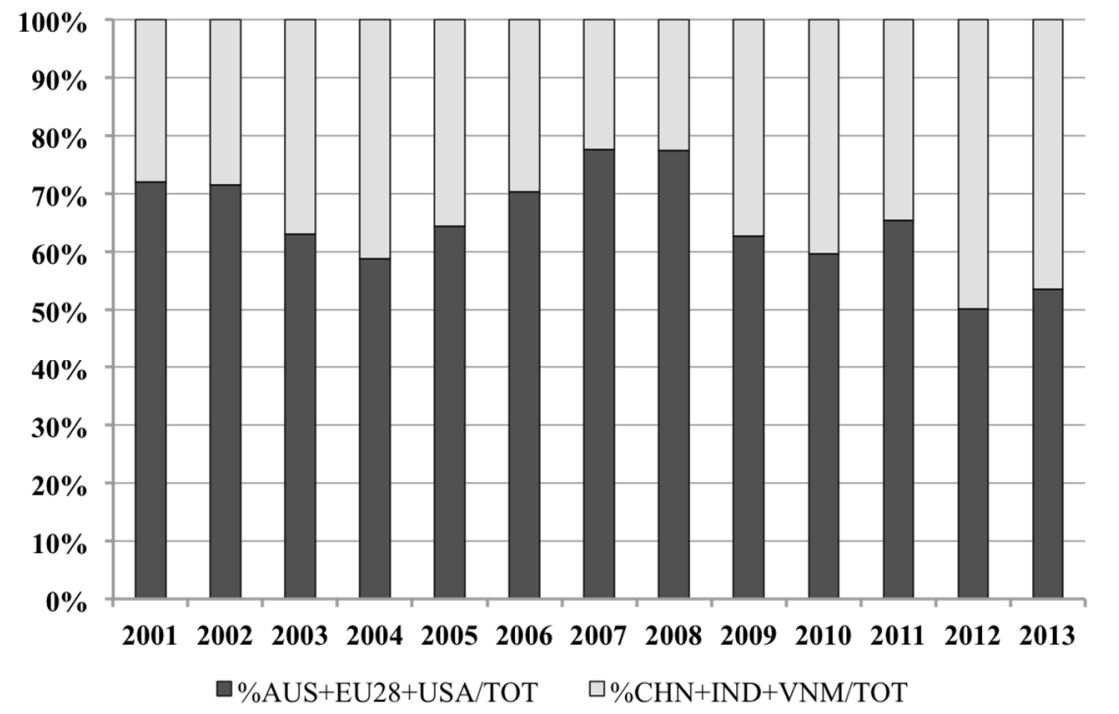

Figure B2. (a) Tropical timber product imports by groups of selected countries from VPA countries, in volume; and (b) \% incidence of selected countries on total imports (2001-2013). AUS = Australia; CHN = China; EU-28 = European Union; IND = India; $\mathrm{USA}=$ United States of America; VNM = Vietnam. Difference means difference between $($ AUS + EU-28 + USA) and (CHN + IND + VNM). Source: own elaboration from [43]. 
a. volume

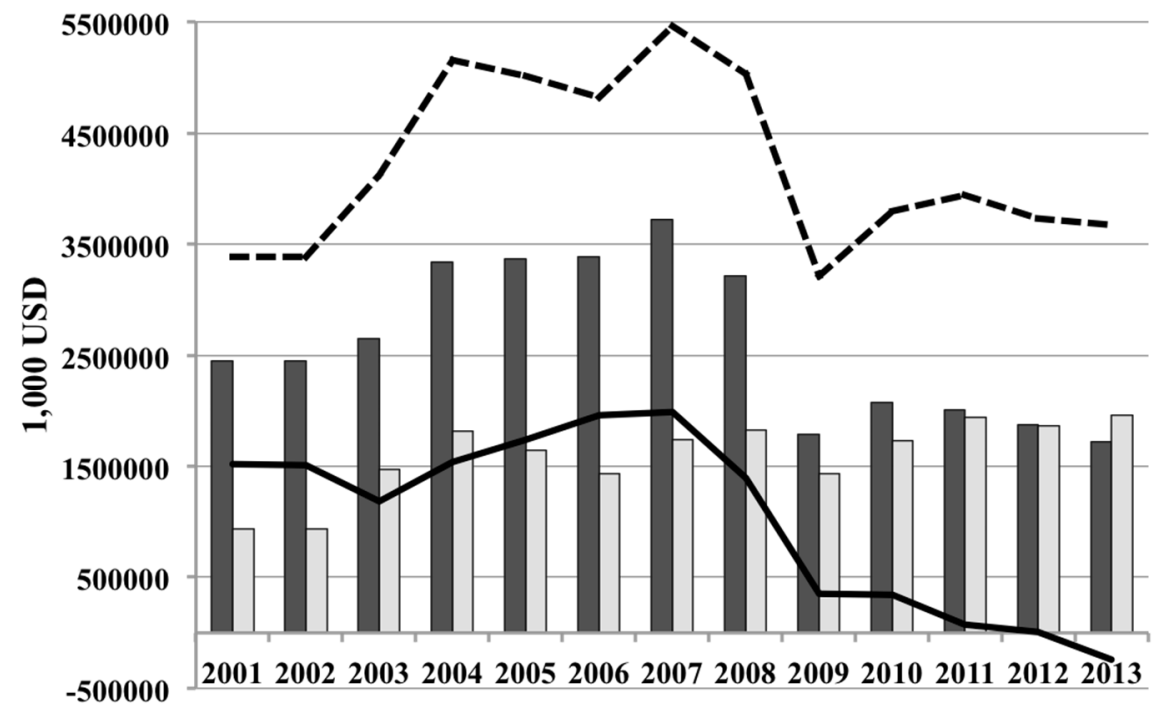

AUS+EU28+USA $\square$ CHN+IND+VNM -Difference ---Total

b. value

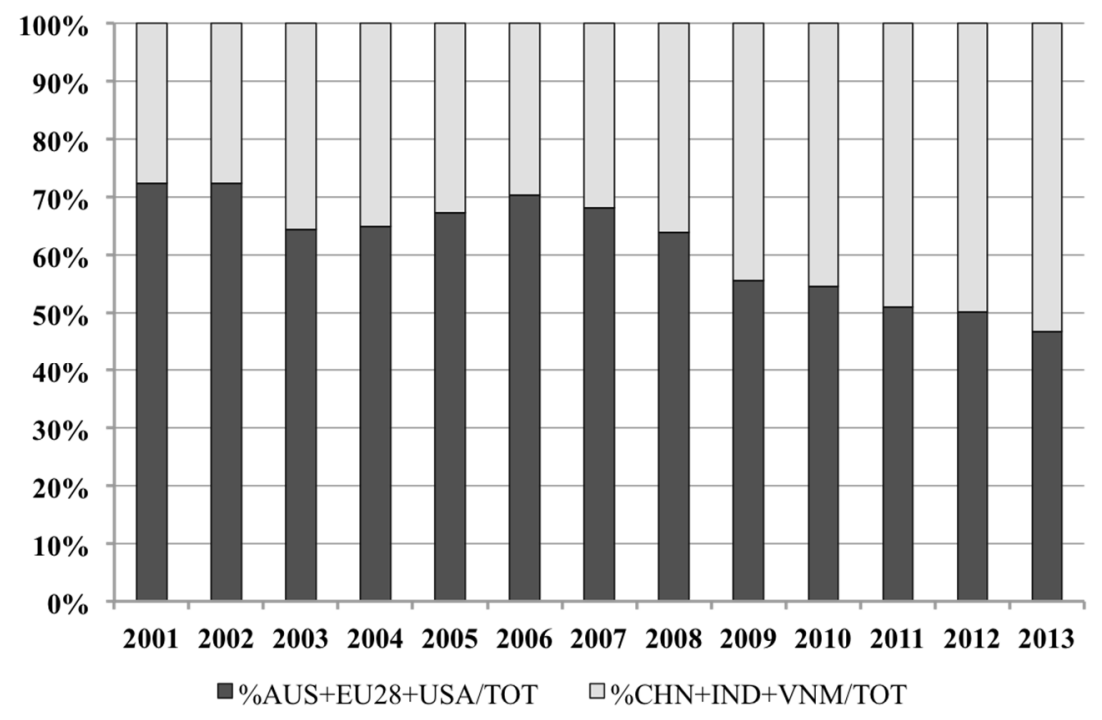

Figure B3. (a) Tropical timber product imports by groups of selected countries, in value; and (b) \% incidence of selected countries on total imports (2001-2013). AUS = Australia; $\mathrm{CHN}=$ China; EU-28 = European Union; IND = India; USA = United States of America; $\mathrm{VNM}=$ Vietnam. Difference means difference between (AUS + EU-28 + USA) and $(\mathrm{CHN}+\mathrm{IND}+\mathrm{VNM})$. Source: own elaboration from [43]. 
a. volume

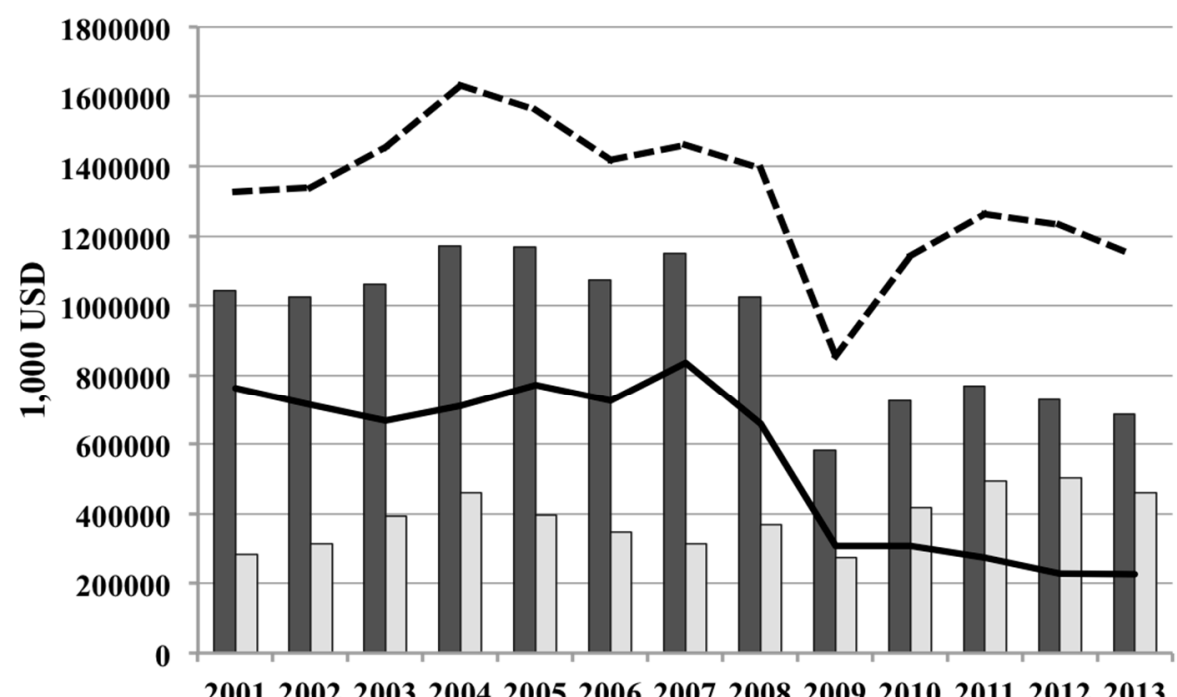

2001200220032004200520062007200820092010201120122013

$\square$ AUS+EU28+USA $\square$ CHN+IND+VNM $\longrightarrow$ Difference $-\boldsymbol{-}$-Total

b. value

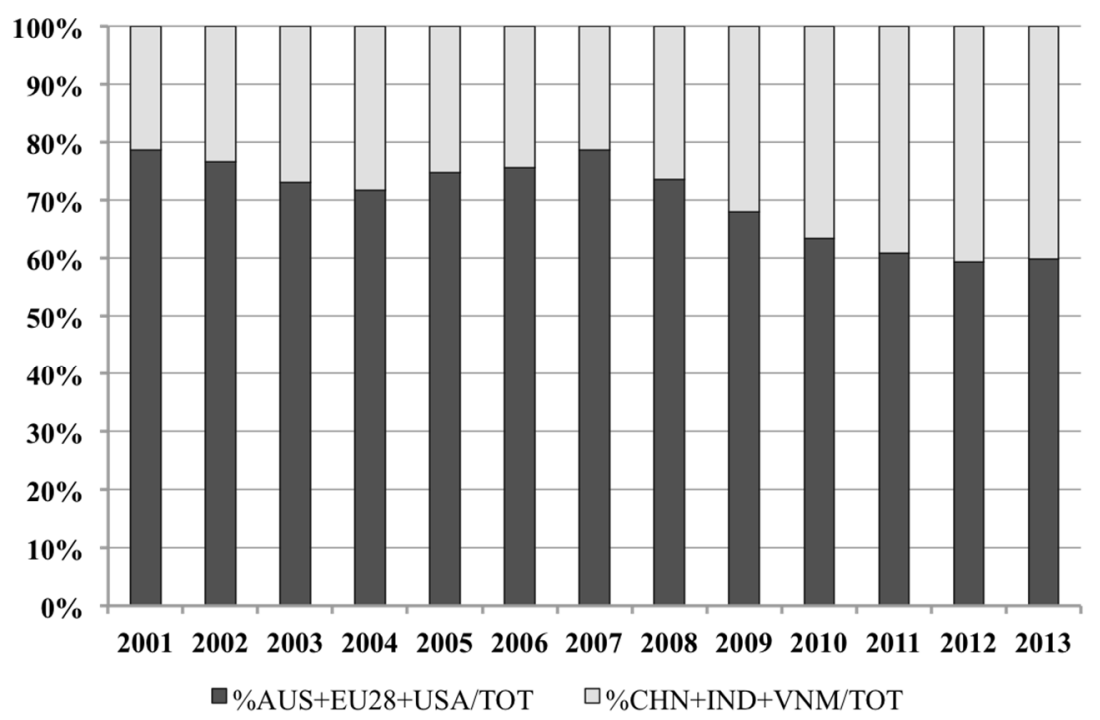

Figure B4. (a) Tropical timber product imports by groups of selected countries from VPA countries, in value; and (b) \% incidence of selected countries on total imports (2001-2013). AUS = Australia; CHN = China; EU-28 = European Union; IND = India; $\mathrm{USA}=$ United States of America; VNM = Vietnam. Difference means difference between (AUS + EU-28 + USA) and (CHN + IND + VNM). Source: own elaboration from [43]. 


\section{a. 4403 Logs}

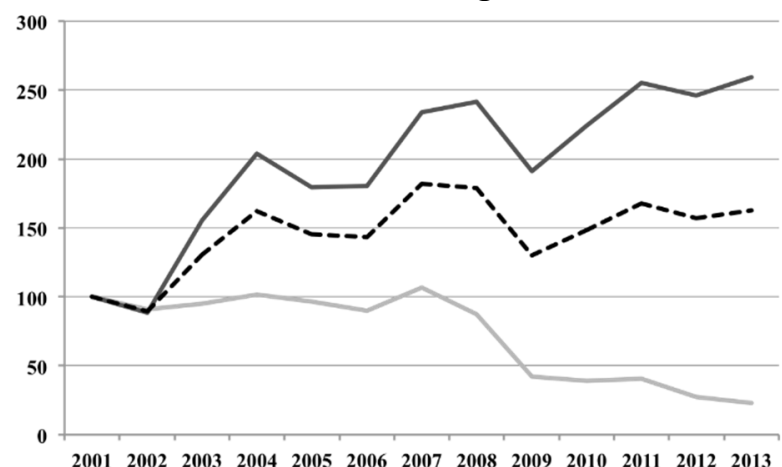

-AUS-EU28-USA - CHN-IND-VNM --•TOT

a. 4407 Sawnwood

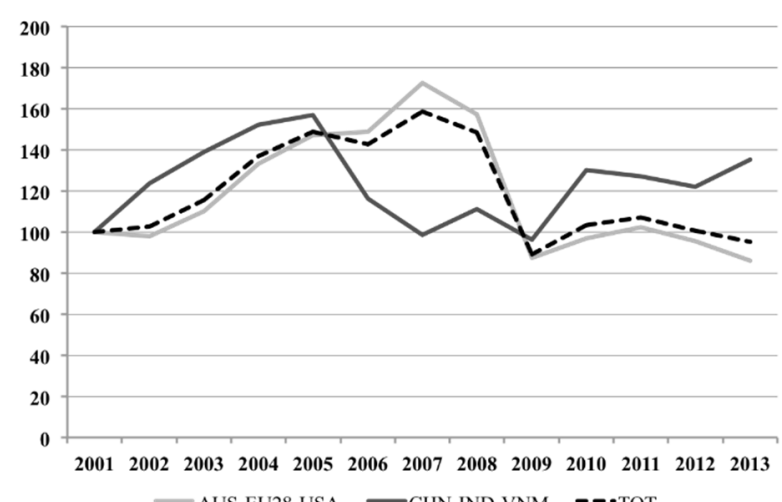
-AUS-EU28-USA -CHN-IND-VNM - - TOT

\section{a. 4408 Veneer}

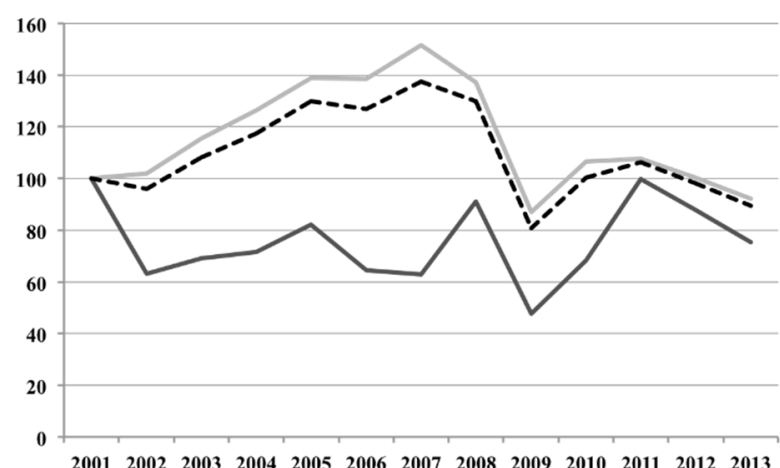

- AUS-EU28-USA - CHN-IND-VNM --•TOT

\section{a. 4412 Plywood}

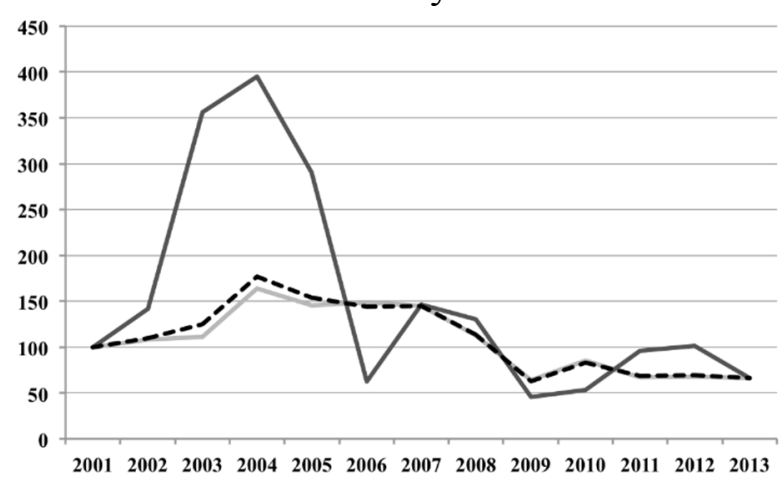

b. 4403 Logs

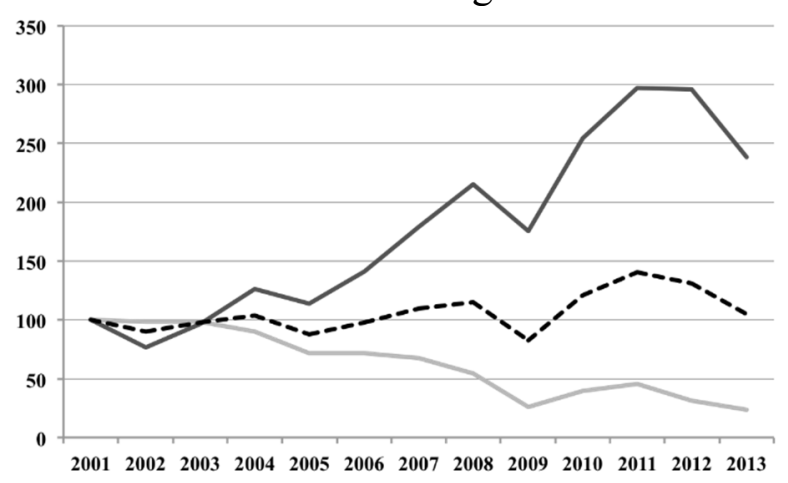

-AUS-EU28-USA - CHN-IND-VNM --・TOT

b. 4407 Sawnwood

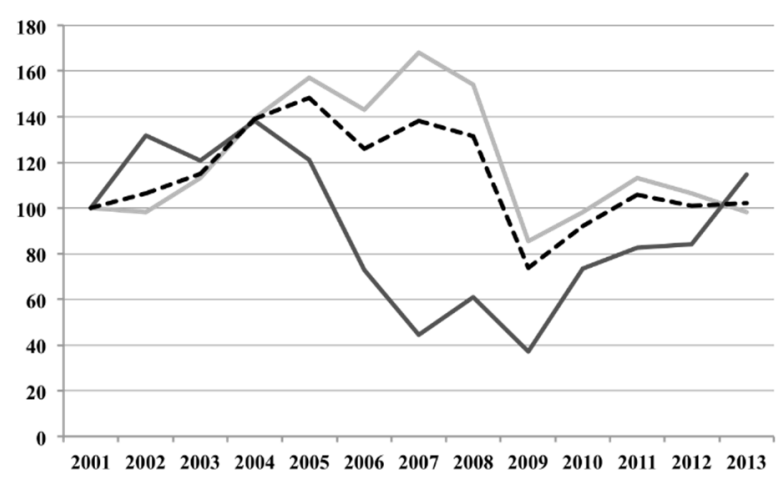
-AUS-EU28-USA - CHN-IND-VNM --•TOT

\section{b. 4408 Veneer}

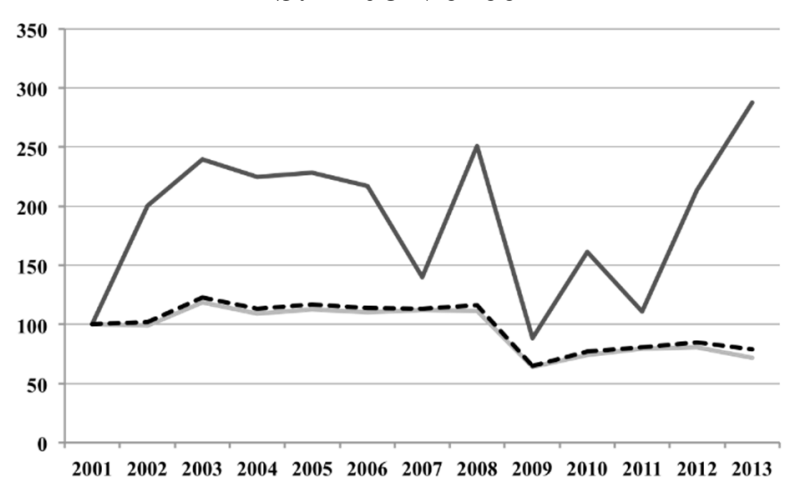
-AUS-EU28-USA - CHN-IND-VNM --・TOT

\section{b. 4412 Plywood}

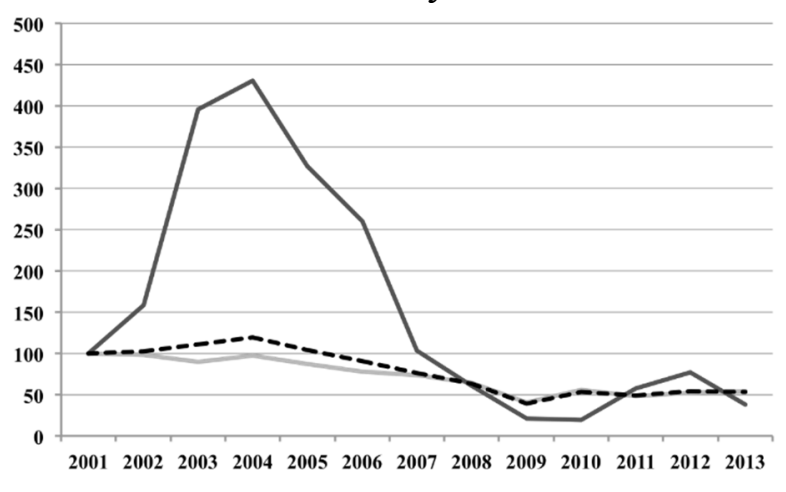

Figure B5. Cont. 
a. Total

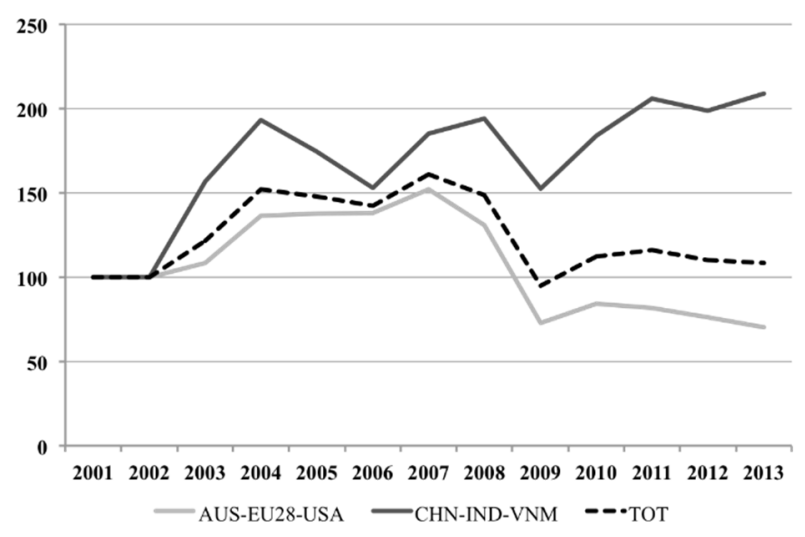

b. Total

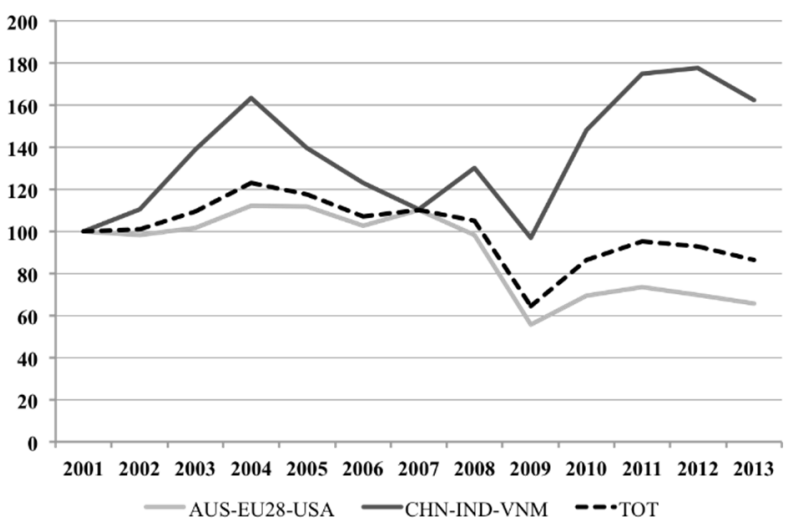

Figure B5. Evolution of tropical timber product imports by groups of selected countries, in values indexed to $2001(2001=100)$ : (a) total imports and (b) imports from VPA countries (2001-2013). AUS = Australia; CHN = China; EU-28 = European Union; IND = India; $\mathrm{USA}=$ United States of America; VNM = Vietnam. Source: own elaboration from [43].

\section{References}

1. Tacconi, L. Introduction. In Illegal Logging. Law Enforcement, Livelihoods and the Timber Trade, 1st ed.; Tacconi, L., Ed.; Earthscan: London, UK, 2007; pp. 1-16.

2. Contreras-Hermosilla, A. Law Compliance in the Forestry Sector: An Overview; World Bank: Washington, DC, USA, 2002; p. 40.

3. Seneca Creek Associates and Wood Resources International. "Illegal" Logging and Global Wood Markets: The Competitive Impacts on the U.S. Wood Products Industry; Summary American Forest and Paper Association: Washington, DC, USA, 2004; p. 19.

4. World Bank. Strengthening Forest Law Enforcement and Governance. Addressing A Systemic Constraint to Sustainable Development; Report No. 36638-GLB; World Bank; Environment and Agriculture and Rural Development Departments; Sustainable Development Network: Washington, DC, USA, 2006; p. 77.

5. Hirschberger, P. Illegal Wood for the European Market. An Analysis of the EU Import and Export of Illegal Wood and Related Products; WWF: Geneva, Switzerland, 2008; p. 45.

6. Lawson, S.; MacFaul, L. Illegal Logging and Related Trade: Indicators of the Global Response; Chatham House: London, UK, 2010; p. 154.

7. Bosello, F.; Parrado, R.; Rosa, R. The economic and environmental effects of an EU ban on illegal logging imports. Insights from a CGE assessment. Environ. Dev. Econ. 2013, 18, 184-206.

8. Mukul, S.A.; Herbohn, J.; Rashid; A.Z.M.M.; Uddin, M.B. Comparing the effectiveness of forest law enforcement and economic incentive to prevent illegal logging in Bangladesh. Int. For. Rev. 2014, 16, 363-375.

9. Mittermeier, R.A.; Schwitzer, C.; Rylands, A.B.; Taylor, L.A.; Chiozza, F.; Williamson, E.A.; Wallis, J. Primates in Peril: The World's 25 Most Endangered Primates 2012-2014; IUCN/SSC Primate Specialist Group (PSG); International Primatological Society (IPS); Conservation International (CI); Bristol Conservation and Science Foundation: Arlington, VA, USA, 2014; p. 87. 
10. Pedroni, L.; Dutschke, M.; Streck, C.; Estrada Porrúa, M. Creating incentives for avoiding further deforestation: The nested approach. Clim. Policy 2009, 9, 207-220.

11. Human Rights Watch. Wild Money: The Human Rights Consequences of Corruption and Illegal Logging in Indonesia's Forestry Sector; Human Rights Watch: New York, NY, USA, 2009; p. 75.

12. Smith, J.; Obidzinski, K.K.; Subarudi, S.; Suramenggala, I. Illegal logging, collusive corruption and fragmented governments in Kalimantan, Indonesia. Int. For. Rev. 2003, 5, 293-302.

13. Transparency International. Analysing Corruption in the Forestry Sector. Forest Governance Integrity Programme; Transparency International: Berlin, Germany, 2010; p. 102.

14. Goncalves, P.M.; Panjer, M.; Greenberg, T.S.; Magrath, W.B. Justice for Forests. Improving Criminal Justice Efforts to Combat Illegal Logging; World Bank: Washington, DC, USA, 2012; p. 56.

15. Springer. Extreme Conflict and Tropical Forests, 1st ed.; de Jong, W., Donovan, D., Abe, K., Eds.; Springer: Dordrecht, The Netherlands, 2007; p. 184.

16. UNEP; INTERPOL. Green Carbon, Black Trade: Illegal Logging, Tax Fraud and Laundering in the World's Tropical Forests; United Nations Environment Programme and the International Criminal Police Organization: Nairobi, Kenya, 2012; p. 72. Available online: http://www.unep.org/ pdf/RRAlogging_english_scr.pdf (accessed on 23 May 2015).

17. Bisschop, L. Out of the woods: The illegal trade in tropical timber and a European trade hub. Glob. Crime 2012, 13, 191-212.

18. Overdevest, C.; Zeitlin, J. Constructing a transnational timber legality assurance regime: Architecture, accomplishments, challenges. For. Policy Econ. 2014, 48, 6-15.

19. Moiseyev, A.; Solberg, B.; Michie, B.; Kallio, A.M.I. Modeling the impacts of policy measures to prevent import of illegal wood and wood products. For. Policy Econ. 2010, 12, 24-30.

20. European Commission. Regulation (EU) No 995/2010 of the European Parliament and of the Council of 20 October 2010 Laying down the Obligations of Operators Who Place Timber and Timber Products on the Market; Official Journal of the European Union L 295: Brussels, Belgium, 2010; pp. 23-34.

21. US Congress. Public Law 110-234. Food, Conservation, and Energy Act of 2008. Available online: www.gpo.gov/fdsys/pkg/PLAW-110pub1234/pdf/PLAW-110publ234.pdf (accessed on 23 May 2015).

22. Australian Government. Illegal Logging Prohibition Act 2012. No. 166, 2012. An Act to Combat Illegal Logging, and for Related Purposes. Available online: www.comlaw.gov.au/Details/ C2012A00166 (accessed on 23 May 2015).

23. Jonsson, R.; Giurca, A.; Masiero, M.; Pepke, E.; Pettenella, D.; Prestemon, J.; Winkel, G. Assessment of the EU Timber Regulation and FLEGT Action Plan. From Science to Policy 1; European Forest Institute: Joensu, Finland, 2015; p. 32.

24. Giurca, A.; Jonsson, R.; Rinaldi, F.; Priyadi, H. Ambiguity in timber trade regarding efforts to combat illegal logging: Potential impacts on trade between South-East Asia and Europe. Forests 2014, 4, 730-750.

25. Prestemon, J.P. The impacts of the Lacey Act Amendment of 2008 on U.S. hardwood lumber and hardwood plywood imports. For. Policy Econ. 2015, 50, 31-44. 
26. Bridegam, P.; Eastin, I. The effects of the 2008 Lacey Act amendment on international trade in forest products. For. Chron. 2014, 90, 643-650.

27. Gan, J.; Cashore, B.; Stone, M.W. Impacts of the Lacey Act Amendment and the Voluntary Partnership Agreements on illegal logging: Implications for global forest governance. J. Nat. Resour. Policy Res. 2013, 5, 209-226.

28. Fishman, A.; Obidzinski, K. Verified legal? Ramifications of the EU timber regulation and Indonesia's voluntary partnership agreement for the legality of Indonesian timber. Int. For. Rev. 2015, 17, 10-19.

29. Carden, C.; Wijers, R.; Zambon, P. FLEGT, VPA, EUTR and Their Possible Impact on the Bolivian Timber Sector. S-FOR-S: CBI FLEGT Bolivia; Final Report 15/06/12; CBI Ministry of Foreign Affairs of the Netherlands: Amsterdam, the Netherlands, 2012; p. 44.

30. Roe, B.; Eastin, I.; Ganguly, I. The impact of timber legality regulations on business practices in Vietnam. For. Chron. 2014, 90, 651-659.

31. Trishkin, M.; Lopatin, E.; Karjalainen, T. Exploratory assessment of a company's due diligence system against the EU timber regulation: A case study from northwestern Russia. Forests 2015, 6 , 1380-1396.

32. European Commission. Accompanying Document to the Proposal for a Regulation of the European Parliament and of the Council Determining the Obligations of Operators Who Make Timber and Timber Products Available on the Market. Impact Assessment. Available online: http://ec.europa.eu/environment/forests/pdf/impact_assessment.pdf (accessed on 23 May 2015).

33. European Commission. Council Regulation (EC) No 2173/2005 of 20 December 2005 on the Establishment of a FLEGT Licensing Scheme for Imports of Timber into the European Community; Official Journal of the European Union L 347: Brussels, Belgium, 2005; pp. 1-6.

34. Oldenburger, J.; van Benthem, M.; de Groot, C.; Boosten, M.; Jansen, P. Import of Secondary Timber Products by the EU-28. The Netherlands in Focus; Stichting Probos: Wageningen, the Netherlands, 2014; p. 92.

35. WWF-UK. In or out? In Can the European Union's Timber Regulation Keep out Illegal Timber? WWF-UK Working Group: London, UK, 2015; p. 39.

36. Forest Trends. Timber Markets and Trade between Laos and Vietnam: A Commodity Chain Analysis of Vietnamese-Driven Timber Flows; Forest Trends: Washington, DC, USA, 2010; p. 37.

37. Lawson, S. Illegal Wood Import and Re-Export: The Scale of the Problem and the Response in Thailand, South Korea and India; Energy, Environment and Resources EER PP 2014/01; Chatham House: London, UK, 2014; p. 26.

38. Manoharan, T.R. Effects of the EU Timber Regulation and the Demand for Certified Legal Timber on Business and Industry in India; European Forest Institute: Joensuu, Finland, 2013; p. 52.

39. Saunders, J. Trade in Illegal Timber. The Response in Vietnam. A Chatham House Assessment; Chatham House: London, UK, 2014; p. 25.

40. Australian Minister for Agriculture, Fisheries and Forestry. Illegal Logging Prohibition Bill 2011. Explanatory Memorandum. Available online: http://parlinfo.aph.gov.au/parlInfo/search/display/ display.w3p;query=Id\%3A\%22legislation\%2Fems\%2Fr4740_ems_40a6be3a-05c3-4c97-82113826d8f5a423\%22 (accessed on 23 May 2015). 
41. Chatham House. Chatham House Illegal Logging Indicators Country Report Cards; Chatham House: London, UK, 2010. Available online: http://www.illegal-logging.info (accessed on 23 May 2015).

42. Environmental Investigation Agency. US Lacey Act. Available online: http://www.eiaglobal.org/lacey/ (accessed on 23 May 2015).

43. UN COMTRADE Database. Available online: http://comtrade.un.org (accessed on 23 May 2015).

44. ITTO. Annual Review and Assessment of the World Timber Situation 2012; International Tropical Timber Organization: Yokohama, Japan, 2012; p. 196.

45. Adams, M. Is this the end for thin-panel tropical plywood? ITTO Trop. For. Update 2003, 13, 18-19.

46. Eastin, I.; Brose, I.; Maplesden, F.; Novoselov, I. Wood-based panel. In Forest Products Annual Market. Review 2013-2014; UNECE/FAO Timber Committee, United Nations: Geneva, Switzerland, 2014; pp. 61-72.

47. EIA. Crossroads. The Illicit Timber Trade between Laos and Vietnam; Environmental Investigation Agency: London, UK, 2011; pp. 21.

48. UNECE/FAO. Forest Products Annual Market Review 2013-2014; UNECE/FAO Timber Committee, United Nations: Geneva, Switzerland, 2014; p. 156.

49. Eastin, I.; Hendrickx, B.; Burdin, N. Wood-based panels markets, 2008-2009. In Forest Products Annual Market. Review 2008-2009; UNECE/FAO Timber Committee, United Nations: Geneva, Switzerland, 2009; pp. 75-84.

50. ITTO. Riding out the storm. Improving Resilience of the Tropical Timber Sector to the Impacts of Global and Regional Economic and Financial Crises; ITTO Technical Series No. 41; International Tropical Timber Organization: Yokohama, Japan, 2012; p. 149.

51. Pepke, E.; Bowyer, J.; Bratkovich, S.; Fernholz, K.; Groot, M.F.H.; Howe, J. Impacts of Policies to Eliminate Illegal Timber Trade; Dovetail Partners Inc.: Minneapolis, MN, USA, 2015; p. 19.

52. Karsenty, A.; Bayol, N. Chapter 9: 2008-2009 Economic crisis and its impact on the forestry sector in central Africa. In The Forests of the Congo Basin. State of the Forest 2010; Commission des Forêts d'Afrique Centrale, COMIFAC: Yaoundé, Cameroon, 2011; pp. 171-181.

53. Dieter, M. Analysis of trade in illegally harvested timber: Accounting for trade via third party countries. For. Policy Econ. 2009, 11, 600-607.

54. Cerutti, P.O.; Tacconi, L.; Lescuyer, G.; Nasi, R. Cameroon's hidden harvest: Commercial chainsaw logging, corruption and livelihoods. Soc. Nat. Resour. 2013, 26, 539-553.

55. Cerutti, P.O.; Lescuyer, G. The Domestic Market for Small-Scale Chainsaw Milling in Cameroon: Present Situation, Opportunities and Challenges; Series: Occasional Paper 61; CIFOR: Bogor, Indonesia, 2011; p. 39.

56. European Commission. Moving Towards VPA Implementation. Preparation for the Implementation of the FLEGT Voluntary Partnership Agreement 2011-2012; Voluntary Partnership Agreement Technical Secretariat for Liberia: Monrovia, Liberia, 2013; p. 21.

57. Lescuyer, G.; Ndotit, S.; Ndong, L.B.B.; Tsanga, R.; Cerutti, P.O. Policy Options for Improved Integration of Domestic Timber Markets under the Voluntary Partnership Agreement (VPA) Regime in Gabon; CIFOR Infobrief No. 82; CIFOR: Bogor, Indonesia, 2014; p. 4. 
58. UN. Trade Statistics in Policymaking-A Handbook of Commonly Used Trade Indices and Indicators; (Series: Studies in Trade and Investment); United Nations, Economic and Social Commission for Asia and the Pacific (UNESCAP): Bangkok, Thailand, 2011; p. 128.

59. Pettenella, D.; Vidale, E.; da Re, R.; Lovric, M. NWFP in the International Market: Current Situation and Trends; StarTree Project deliverable 3.1; TeSAF Department, University of Padova: Padova, Italy, 2014; p. 31.

(C) 2015 by the authors; licensee MDPI, Basel, Switzerland. This article is an open access article distributed under the terms and conditions of the Creative Commons Attribution license (http://creativecommons.org/licenses/by/4.0/). 